\title{
Temperate Oligocene surface ocean conditions offshore of Cape Adare, Ross Sea, Antarctica
}

\author{
Frida S. Hoem ${ }^{1}$, Luis Valero ${ }^{2}$, Dimitris Evangelinos ${ }^{3}$, Carlota Escutia $^{3}$, Bella Duncan ${ }^{4}$, Robert M. McKay ${ }^{4}$, \\ Henk Brinkhuis ${ }^{1,5}$, Francesca Sangiorgi ${ }^{1}$, and Peter K. Bijl ${ }^{1}$ \\ ${ }^{1}$ Department of Earth Sciences, Utrecht University, Utrecht, the Netherlands \\ ${ }^{2}$ Department of Earth Sciences, University of Geneva, Geneva, Switzerland \\ ${ }^{3}$ Department of Marine Geoscience, Instituto Andaluz de Ciencias de la Tierra, Consejo Superior de Investigaciones \\ Cientificas (CSIC)-Universidad de Granada, Armilla, Spain \\ ${ }^{4}$ Antarctic Research Centre, Victoria University of Wellington, Wellington, New Zealand \\ ${ }^{5}$ Royal Netherlands Institute for Sea Research (NIOZ), Texel, the Netherlands
}

Correspondence: Frida S. Hoem (f.s.hoem@uu.nl)

Received: 28 October 2020 - Discussion started: 27 November 2020

Revised: 18 May 2021 - Accepted: 31 May 2021 - Published: 2 July 2021

\begin{abstract}
Antarctic continental ice masses fluctuated considerably during the Oligocene "coolhouse", at elevated atmospheric $\mathrm{CO}_{2}$ concentrations of $\sim 600-800 \mathrm{ppm}$. To assess the role of the ocean in the Oligocene ice sheet variability, reconstruction of past ocean conditions in the proximity of the Antarctic margin is needed. While relatively warm ocean conditions have been reconstructed for the Oligocene offshore of Wilkes Land, the geographical extent of that warmth is unknown. In this study, we reconstruct past surface ocean conditions from glaciomarine sediments recovered from Deep Sea Drilling Project (DSDP) Site 274 offshore of the Ross Sea continental margin. This site, located offshore of Cape Adare is ideally situated to characterise Oligocene regional surface ocean conditions, as it is situated between the colder, higher-latitude Ross Sea continental shelf and the warm-temperate Wilkes Land margin in the Oligocene. We first improve the age model of DSDP Site 274 using integrated bio- and magnetostratigraphy. Subsequently, we analyse organic walled dinoflagellate cyst assemblages and lipid biomarkers TEX $_{86}$, TetraEther indeX of 86 carbon atoms) to reconstruct surface palaeoceanographic conditions during the Oligocene (33.7-24.4 Ma). Both TEX $_{86}$ based sea surface temperature (SST) and microplankton results show temperate $\left(10-17^{\circ} \mathrm{C} \pm 5.2^{\circ} \mathrm{C}\right)$ surface ocean conditions at Site 274 throughout the Oligocene. Oceanographic conditions between the offshore Wilkes Land margin and Cape Adare became increasingly similar towards the late
\end{abstract}

Oligocene (26.5-24.4 Ma); this is inferred to be the consequence of the widening of the Tasmanian Gateway, which resulted in more interconnected ocean basins and frontal systems. Maintaining marine terminations of terrestrial ice sheets in a proto-Ross Sea with offshore SSTs that are as warm as those suggested by our data requires a strong ice flux fed by intensive precipitation in the Antarctic hinterland during colder orbital states but with extensive surface melt of terrestrial ice during warmer orbital states.

\section{Introduction}

The Southern Ocean plays a crucial role in global ocean circulation, stability of the Antarctic ice sheet and the carbon cycle. At present, strong temperature gradients isolate Antarctica from the influence of warmer surface water from lower-latitude regions. Despite its crucial role, little is currently known about the evolution of the Southern Ocean. Southern Ocean surface conditions cooled during the midEocene (<49 Ma; Bijl et al., 2009, 2013), which culminated in the initiation of Antarctic continental-scale glaciation at the Eocene-Oligocene transition (EOT 33.7 Ma; Zachos et al., 1994; Coxall et al., 2005; Bohaty et al., 2012). The overall higher bedrock elevation and larger subaerial area of Antarctica during the Oligocene (33.9-23.0 Ma; Gradstein et al., 2012; Wilson et al., 2013; Paxman et al., 2019) al- 
lowed for the occupation of large terrestrial ice caps. Antarctic ice-proximal records suggest that these ice sheets extended onto the coast, forming ice margins with marine terminations (Escutia et al., 2011; Scher et al., 2011; Galeotti et al., 2016). Apparently, Southern Ocean temperatures at the earliest Oligocene oxygen isotope step (EOIS) cooled enough to sustain the marine-terminating ice sheets. Following the EOIS, deep-sea $\delta^{18} \mathrm{O}$ gradually rebounded (Zachos et al., 2008), suggesting long-term loss of Antarctic ice and/or gradual deep-sea warming. Indeed, the Oligocene remained a relatively warm time interval globally (O'Brien et al., 2020). However, on orbital timescales, Oligocene Antarctic ice volume underwent major fluctuations in size (e.g. Pälike et al., 2006; Galeotti et al., 2016; McKay et al., 2016; Liebrand et al., 2017; Levy et al., 2019), and the role Southern Ocean sea surface temperature (SST) conditions played in these fluctuations still remains poorly understood, mostly due to the sparse geographic coverage of reconstructions of Oligocene SSTs.

Warm-temperate Oligocene SSTs $\left(13-25^{\circ} \mathrm{C}\right)$ and frontal system reconstructions at the Wilkes Land margin were derived from organic walled dinoflagellate cyst (dinocyst) assemblages at Deep Sea Drilling Project (DSDP) Site 269 (Evangelinos et al., 2020) and Integrated Ocean Drilling Program (IODP) Site U1356 (Bijl et al., 2018b). These were corroborated with quantitative SSTs based on organic biomarkers TEX $_{86}$, TetraEther indeX of 86 carbon atoms; Hartman et al., 2018) and with sedimentological and lithological interpretations (Salabarnada et al., 2018; Evangelinos et al., 2020). Data seem to indicate a southward displacement of the (proto-) Southern Ocean fronts, perhaps favoured by the still constricted, narrow Tasmanian Gateway (Scher et al., 2015), and consequent southward deflection of warm ocean currents (Fig. 1b). The relative absence of icebergrafted debris in most of the Oligocene sedimentary record of IODP Site U1356 (Escutia et al., 2011; Salabarnada et al., 2018; Passchier et al., 2019) suggests that the East Antarctic Ice Sheet (EAIS) in the Wilkes Land sector may have been predominately land based, indicating limited ice sheetocean interaction in this sector of the EAIS. Sedimentary records recovered from cores located near the Transantarctic Mountain outlet glaciers, such as DSDP Site 270 (Kulhanek et al., 2019), CIROS-1 (Cenozoic Investigations of the Ross Sea-1; Barrett, 1989) and Cape Roberts Project (CRP) (Naish et al., 2001; Prebble et al., 2006; Houben et al., 2013) have provided important insights into widespread advances of both the East and West Antarctic ice sheets, terminating into the western Ross Sea. TEX 86 -based SST records indicate lower temperatures $\left(6-14^{\circ} \mathrm{C}\right)$ in the Ross Sea during the Oligocene (Levy et al., 2016; Duncan, 2017) than offshore of the Wilkes Land margin (Hartman et al., 2018), suggesting a large $\left(\sim 7^{\circ} \mathrm{C}\right)$, much larger than present, (sub-) surface ocean temperature difference between the two sectors. However, it remains unknown if the warm conditions offshore of the Wilkes Land margin were unique or if similar tempera- tures existed close to the Ross Sea continental shelf in the Oligocene.

To this end, we investigated sediments recovered during DSDP Leg 28 at Site 274, located on the offshore continental rise in the Ross Sea, $\sim 250 \mathrm{~km}$ northwest of Cape Adare (Hayes et al., 1975), which is at an intermediate location between the aforementioned sites in the Ross Sea and offshore of Wilkes Land (Fig. 1). DSDP Leg 28 retrieved valuable sedimentary records from the continental shelf and rise regions of the Ross Sea, but poor age control has long hampered their use in reconstructing past ocean conditions. Moreover, the archives were devoid of calcareous foraminifers, denying the use of their wall geochemistry, which is typically utilised for the reconstruction of ocean conditions. Studies based on dinocysts have, however, allowed both age control and palaeoceanographic interpretations as, for example, the result of the established connection between dinocyst assemblage composition and surfacewater conditions of the present-day Southern Ocean (Prebble et al., 2013; Zonneveld et al., 2013; Marret et al., 2019). Recent dinocyst records from the Ross Sea region, notably CRP (Clowes et al., 2016) and DSDP Site 270 (Kulhanek et al., 2019), and from Wilkes Land, IODP Site U1356 (Sangiorgi et al., 2018; Bijl et al., 2018a, b) and DSDP Site 269 (Evangelinos et al., 2020), have provided new biostratigraphic constraints. We used these constraints, alongside new biostratigraphic and magnetostratigraphic analyses, to improve the age model of DSDP Site 274. We then interpret palaeoceanographic conditions with dinocyst assemblages and generate quantitative SST reconstructions with lipid biomarkers $\left(\right.$ TEX $\left._{86}\right)$. By comparing these results with available reconstructions from the Ross Sea and Wilkes Land in selected time slices, we evaluate how surface oceanographic conditions changed and latitudinal heat transport developed through the Oligocene.

\section{Material}

\subsection{Site description}

DSDP Site $274\left(68^{\circ} 59.81^{\prime} \mathrm{S} ; 173^{\circ} 25.64^{\prime} \mathrm{E} ; 3326 \mathrm{~m}\right.$ water depth; Fig. 1a), is located on the lower continental rise in the northwestern Ross Sea, about $250 \mathrm{~km}$ north-northeast of Cape Adare (Hayes et al., 1975). Sediments were collected using punch-core rotary drilling on the Glomar Challenger in February 1973 (Hayes et al., 1975). Currently, the region is seasonally covered by sea ice (Fetterer et al., 2020), and the present-day mean annual SST is $\sim-1{ }^{\circ} \mathrm{C}$ (Locarnini et al., 2019). The site is in the vicinity of the southern upwelling margin of the Antarctic Divergence and is currently located in the path of a major outflow for Antarctic Bottom Water, spilling out over the western Ross Sea continental shelf where it is deflected westward (Orsi and Wiederwohl, 2009). The location of DSDP Site 274 is ideal for studying the offshore Oligocene oceanic properties in the Ross Sea (Fig. 1b), 
(a)

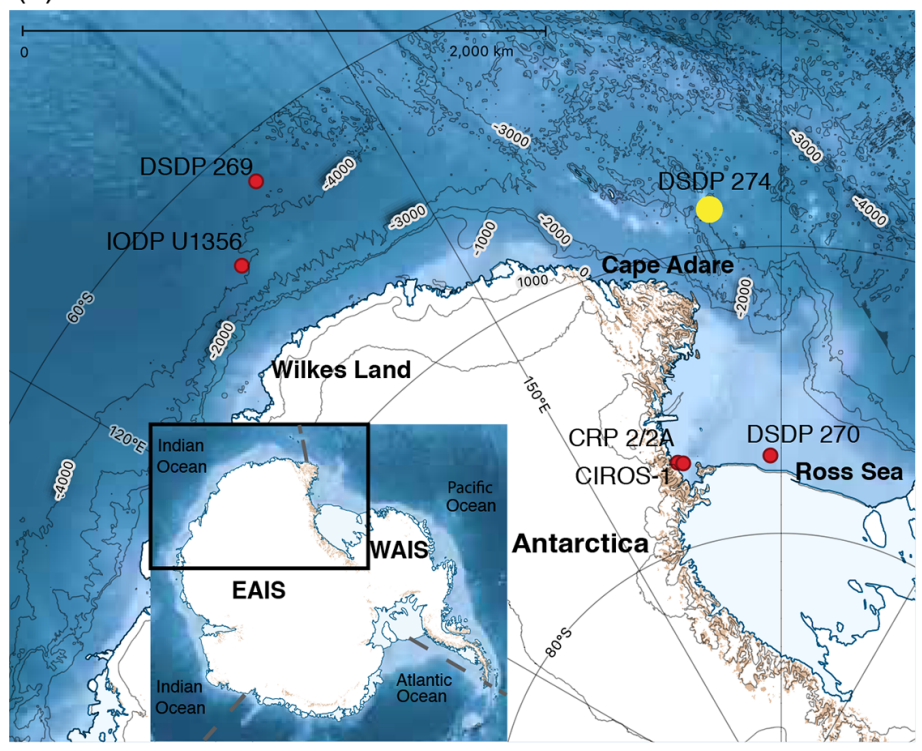

(b)

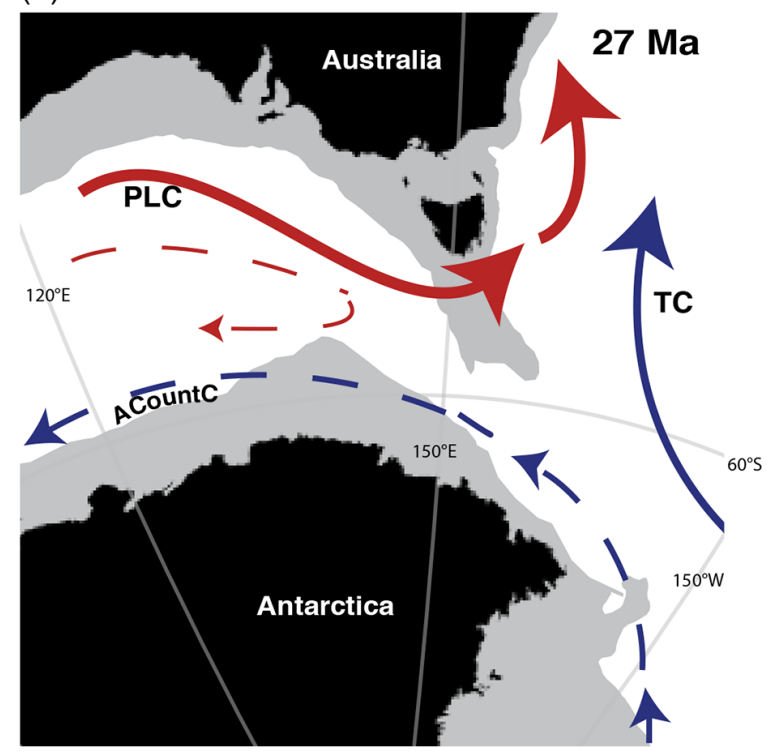

Figure 1. (a) Ross Sea to Wilkes Land margin bathymetry with present-day locations of the DSDP, IODP and CRP drill sites included in this study (red dots). The new data generated for this study are from DSDP Site 274 (yellow dot). The base map is from the Quantarctica GIS package (Norwegian Polar Institute). The inset shows the Antarctic continent and the surrounding oceans (divided by grey dotted lines) to give a broader regional context to the study area. (b) A synthesis of palaeoceanographic settings at 27 Ma. The palaeogeographic position is generated with GPlates (http://www.gplates.org, last access: 13 June 2016), based on the global plates geodynamic motion model from Müller et al. (2018). Light grey indicates the continental lithosphere. The inferred ocean currents are drawn after reconstructions by Stickley et al. (2004); the abbreviation used are as follows: TC is the Tasman Current, PLC is the proto-Leeuwin Current and ACountC is the Antarctic Counter Current. Blue arrows indicate cooler ocean currents, and red arrows indicate warmer ocean currents. Relative current strength is indicated by the arrow size.

which we compare to documented Antarctic ice sheet and ocean conditions from proximal Ross Sea records (Fig. 1a).

\subsection{Lithology and depositional settings}

Drilling at DSDP Site 274 penetrated $421 \mathrm{~m}$ b.s.f. (metres below the sea floor) and recovered a total of 43 cores containing $275.5 \mathrm{~m}$ of sediment. We focus our study on the interval between 174.2 and 408.5 m b.s.f. (cores 19-43; Fig. 2a). Sediment within this interval is mainly composed of (i) diatomrich detrital silty clay with varying abundances of diatoms, from trace amounts to up to $80 \%$ (diatom ooze) (174.2$328 \mathrm{~m}$ b.s.f.), and (ii) silty claystones and interbedded chert layers (328-408.5 m b.s.f.). Scattered iceberg-rafted debris (IRD; pebbles and granules) has been documented between 152 and 323 m b.s.f. Below 323 m b.s.f., chert layers compromised core recovery, and at $415 \mathrm{~m}$ b.s.f., the basalt basement was reached (Hayes et al., 1975). The sediment cores are rather homogenous and lack strong sedimentary structures. The strong biscuiting and fracturing of lithified sediment testify to drilling disturbance due to the rough nature of rotary drilling and may have obscured depositional sedimentary structures. Downslope transport of sediment from the Ross Sea continental shelf to the site potentially complicates the reconstruction of local pelagic-derived ocean con- ditions. The lithology and the seismic patterns (Hayes et al., 1975) suggest that sediment in the Oligocene was transported and deposited within the Adare Basin through a combination of downslope gravity currents and subsequent reworking by bottom currents (Hayes et al., 1975).

\section{Methods}

\subsection{Age model}

The shipboard age model (Hayes et al., 1975), based on a few biostratigraphic (diatom, radiolarian and calcareous nannofossils) age tie points, initially dated the DSDP Site 274 sedimentary record overlying the basalt to late EoceneQuaternary. More recently, Cande et al. (2000) dated the ocean crust underneath DSDP Site 274, using palaeomagnetic data, to chron $13, \sim 33.5 \mathrm{Ma}$, which is $200 \mathrm{kyr}$ younger than the EOT and 5-7 Myr younger than it was dated during the expedition (Hayes et al., 1975). Granot et al. (2010) formulated seismic stratigraphic units and correlated these units with the Ross Sea continental shelf. The lowermost regional unconformity (328 $\mathrm{m}$ b.s.f.) above the basement (Hayes et al., 1975) corresponds to a Ross Sea unconformity (RSU) found in the Northern Basin, RSU6, and estimated to be of earlyOligocene age (34-26.5 Ma; De Santis et al., 1995; Granot et 


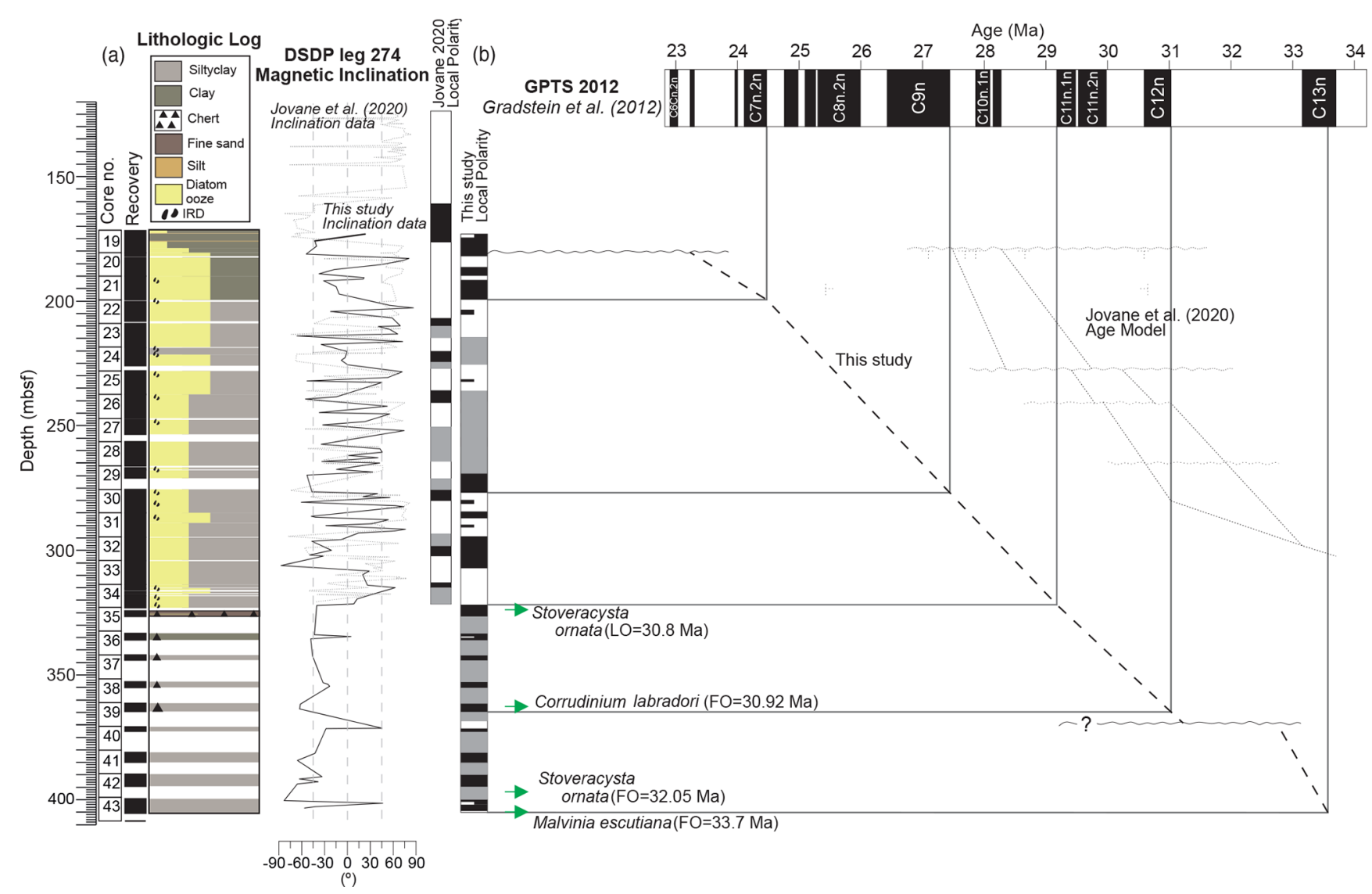

Figure 2. (a) Core numbers, core recovery and lithological description of the cores based on the initial DSDP reports (Hayes et al., 1975). (b) Magnetic correlation for Site 274 with comparison to Jovane et al. (2020) (dotted lines). Inclination values define local magnetic polarity zones. Magnetostratigraphic correlation is firstly guided by new dinocyst constraints, biostratigraphic markers from shipboard reports, and, subsequently, by correlation between local polarity zones and the GTS2012 timescale (Gradstein et al., 2012). Low intensity, shifting directions and low recovery preclude magnetozone identification for some intervals. Characteristic orthoplots showing demagnetisation steps are included in the Supplement (Fig. S1). Arrows indicate age (Ma) biostratigraphic tie points according to the age model described in Table 2. Extrapolation has been carried out between the age tie points (stippled lines), with the sedimentation rates indicated in between. LO denotes last occurrence, and FO denotes first occurrence.

al., 2010; Kulhanek et al., 2019). The major unconformity at $180.5 \mathrm{~m}$ b.s.f., between cores 19 and 20 (Hayes et al., 1975), is tied to seismic reflectors RSU4 and RSU4a (Granot et al., 2010), which are aged to the mid-Miocene, $\sim 15.8-14.6 \mathrm{Ma}$ and $\sim 17 / 16.9$ Ma respectively (Pérez et al., 2021). To further improve the age model, we generated new age tie points based on dinocyst biostratigraphy and magnetostratigraphy to better constrain the age of the sedimentary record (cores 43-17). Dinocyst biostratigraphy follows Bijl et al. (2018a), who reassessed dinocyst species first and last occurrence datums calibrated against the GTS 2012 international geological timescale (Gradstein et al., 2012). Magnetic reversals on the sediment samples were identified through stepwise demagnetisation experiments performed using the $2 \mathrm{G}$ magnetometer with an inline alternating fields (AF) demagnetiser attached to an automatic sample handler in Fort Hoofddijk (Utrecht University) and the 2G-SRM750 Superconducting Rock Magnetometer housed at the Paleomagnetic Labora- tory of Barcelona (CCiTUB-CSIC). As core orientation is not reconstructed, magnetic declinations are discarded and only magnetic inclinations are used to determine polarities. Recently, Jovane et al. (2020) carried out a palaeomagnetic study at the DSDP Site 274 , focusing on magnetic properties and magnetic mineralogy characterisation; by means of a review of the available biostratigraphic constraints, they also propose a new age model. Here, we compare their age model with ours and discuss the differences.

\subsection{Organic geochemistry}

To reconstruct sea (sub-) surface temperature (SST), we applied the $\mathrm{TEX}_{86}$ (TetraEther indeX of 86 carbon atoms) proxy (Schouten et al., 2002), which is based on the temperature-dependent cyclisation of isoprenoidal glycerol dialkyl glycerol tetraethers (GDGTs) produced by thaumarchaeotal membrane lipids. GDGTs were extracted from pow- 
dered and freeze-dried sediments using an accelerated solvent extractor. Lipid extracts were then separated into an apolar, ketone and polar fraction by $\mathrm{Al}_{2} \mathrm{O}_{3}$ column chromatography using hexane : dichloromethane methanol (DMC) $(9: 1$, $v: v)$, hexane : $\mathrm{DCM}(1: 1)$ and $\mathrm{DCM}: \mathrm{MeOH}(1: 1)$ as respective eluents. A total of $99 \mathrm{ng}$ of a synthetic $\mathrm{C}_{46}$ (massto-charge ratio, $m / z=744$ ) GDGT standard was added to the polar fraction, which was subsequently dissolved in hexane : isopropanol $(99: 1, v / v)$ to a concentration of $\sim$ $3 \mathrm{mg} \mathrm{mL}^{-1}$ and filtered over a $0.45 \mu \mathrm{m}$ polytetrafluoroethylene filter. The dissolved polar fractions were injected and analysed by high-performance liquid chromatography-mass spectrometry (HPLC-MS), using double-column separation (Hopmans et al., 2016). GDGT peaks in the HPLC chromatograms were integrated using ChemStation software.

\subsubsection{TEX 86 calibrations}

Several calibrations exist to convert $\mathrm{TEX}_{86}$ values into SSTs based on modern core-top datasets (Kim et al., 2010). We follow the discussion by Hartman et al. (2018) and use the linear calibration by Kim et al. (2010) to calculate the TEX $_{86}$ result into SST, which include the high-latitude core-top values. As we present peak areas of individual GDGTs in the Supplement (Table S2), other calibrations can be plotted as well.

\subsubsection{TEX $_{86}$ overprints and bias}

We use ratios of GDGTs as proxies to detect potential overprinting factors that may bias the pelagic signature of the sedimentary GDGTs. The relative contribution of terrestrial GDGT input has been reconstructed using the branched and isoprenoid tetraether (BIT) index (Hopmans et al., 2004). Samples with BIT index values $>0.4$ may be biased by soiland river-derived GDGTs (Bijl et al., 2013). However, we do note that the validity of this proxy for soil organic matter input is called into question now that it has become clear that branched GDGTs may also be produced in the marine realm (Peterse et al., 2009; Sinninghe Damsté, 2016) and in terrestrial ecosystems that contain crenarchaeol (Pearson et al., 2004). The methane index (Zhang et al., 2011) flags overprint by sedimentary methanogenic activity, the GDGT-2/ GDGT3 ratio (Taylor et al., 2013) signals overprint by archaeal communities dwelling deeper into the water column, and the GDGT-0/Crenarchaeol ratio (Blaga et al., 2009; Sinninghe Damsté et al., 2009; Taylor et al., 2013) flags overprint by in situ production of isoprenoidal GDGTs in lakes and rivers as well as contribution from Euryarchaeota. The ring index (Zhang et al., 2016) can detect deviations from a pelagic character in the GDGT "assemblage". Samples which had overprinting values in these biassing indices were marked as unreliable. High-latitude TEX ${ }_{86}$-SST reconstructions are believed to be skewed towards summer temperatures (Schouten et al., 2013; Ho et al., 2014), but studies around Antarctica have found that archaea appear most abundantly in winter and early spring, with maximum abundances in the subsurface at around $100 \mathrm{~m}$ (e.g. Church et al., 2003; Kalanetra et al., 2009; Massana et al., 1998). However, there is a general agreement that $\mathrm{TEX}_{86}$ captures the relative SST trend (Richey and Tierney, 2016) remarkably well despite these uncertainties, and this will be our main focus when interpreting the results.

\subsection{Palynology}

\subsubsection{Palynological processing and taxonomy}

A total of 50 samples, 2 per core (Core 43-17), were processed for palynology using previously published palynological processing and analytical procedures of the Laboratory of Palaeobotany and Palynology (e.g. Bijl et al., 2018a). Freeze-dried or oven-dried sediment was crushed and weighed (on average $10 \mathrm{~g}, \mathrm{SD}$ of $<1 \mathrm{~g}$ ). A tablet of a known amount of Lycopodium clavatum spores (a marker grain) was added prior to palynological processing to allow for quantification of the absolute number of dinocysts per sample. In order to digest carbonates and silicates, the sediment underwent the following: treatment in $30 \% \mathrm{HCl}$ overnight to remove calcium carbonate; treatment in $38 \%$ $\mathrm{HF}$ overnight to digest silicates; addition of $30 \% \mathrm{HCl}$ to remove fluoride gels; and, finally, centrifugation and decantation. Organic residues were isolated between 250 and $10 \mu \mathrm{m}$ sieve meshes, with the help of an ultrasonic bath to break down and clear out agglutinated organic particles. Residues were mounted on glass slides using glycerine jelly. Palynomorphs were counted using a Leica DM2500 LED transmitted light optical microscope. While the main focus was on dinocysts, terrestrial palynomorphs, acritarchs and prasinophyte algae (unicellular planktonic autotrophs) were quantified as well, and the presence and relative abundance of other organic remains were noted. Dinocyst taxonomy follows Williams et al. (2017), Clowes et al. (2016) and informal species as presented in Bijl et al. (2018a). Specimens were identified to a species level when possible. A minimum of 200 identifiable dinocysts were counted per slide at $400 \times$ magnification, while the remainder of the slide was scanned at $200 \times$ magnification to identify rare taxa not observed during the regular count. Samples with counts of $<50$ in situ specimens were discarded for qualitative assessment. All slides are logged in the collection of the Laboratory of Palaeobotany and Palynology, Utrecht University.

\subsubsection{Dinocyst palaeoecological affinity}

The present-day surface sediment distribution of dinocysts depends mostly on surface-water temperature but also on nutrient availability, salinity, primary productivity and sea ice cover (Dale, 1996; Prebble et al., 2013; Zonneveld et al., 2013). We assume that habitat affinities and trophic levels 
of modern dinoflagellate species remained similar throughout the Oligocene and Neogene, although shifts in environmental preferences have been demonstrated for a very limited number of species, e.g. Impagidinium pallidum (de Schepper et al., 2011). Here, we use the modern relationship between dinocyst occurrence and properties of the overlying water to infer oceanographic conditions in the past for extant species (Bijl et al., 2013; Prebble et al., 2013). To determine the habitat affinities and trophic level of extinct dinoflagellates, we rely on previously published papers where a link to palaeoceanographic proxies for temperature, runoff and/or freshwater input, and nutrient conditions was demonstrated (Bijl et al., 2011, 2018a; Frieling and Sluijs, 2018; Egger et al., 2018). We separate the dinocyst assemblages into gonyaulacoid $(\mathrm{G})$ and protoperidinioid $(\mathrm{P})$ cysts. In the Southern Ocean, G-cysts generally include phototrophic temperate dinocysts, associated with warm oligotrophic open-water conditions (Prebble et al., 2013). At present, G-cysts are rare in close proximity to the Antarctic ice sheet (Prebble et al., 2013). An exception is Impagidinium pallidum which is currently found in low percentages in Antarctic environments in the vicinity of the polar front (Zonneveld et al., 2013). The extant Operculodinium spp., Pyxidinopsis spp., Corrudinium spp., Impagidinium spp. and Nematosphaeropsis labyrinthus are absent or represent a minor component of the polar assemblages. P-cysts are produced by heterotrophic dinoflagellates and are usually found in nutrient-rich environments: river outlets, upwelling areas and sea ice zones (Zonneveld et al., 2013). In the present-day Southern Ocean, where the Antarctic Divergence upwelling favours a dominance of P-cysts, species such as Brigantedinium spp., Selenopemphix spp. and, especially, S. antarctica are common (Prebble et al., 2013). S. antarctica is a species that shows an affinity with sea ice conditions (Zonneveld et al., 2013; Marret et al., 2019).

\subsubsection{Reworked versus in situ dinocysts}

One issue with studying sediment records in the proximity of glaciated margins is separating reworked from in situ species, which is needed for obtaining reliable biostratigraphic constraints and palaeoceanographic signals (Macphail, 2021). In turn, quantifying the history of reworked material through time may yield information about the depositional conditions on the Ross Ice Shelf. In this study, we follow the interpretations of Bijl et al. (2018a) and separated dinocyst species into an assumed reworked and an in situ group a priori (Table 1). We applied statistical analysis to test a priori assumptions (Bijl et al., 2018a) on in situ or reworked dinocyst species and to quantitatively measure co-variability between environmental variables and palynological data. Our palynological data were analysed using correspondence analysis (CA), a linear ordination method to explore the differences in assemblages between samples. The palynological data (relative abundance) were plotted in the C2 software program (Juggins, 2007) using square root transformation.

\section{Results}

\subsection{Revised age model}

Based on four new dinocyst-based first occurrence (FO) and last occurrence (LO) datums found in the DSDP Site 274 record, we provide additional age constraints for the age model upon which we correlate five new palaeomagnetic reversal results to specific magnetic chrons (based on Gradstein et al., 2012; Table 2). Palaeomagnetic results are generally of low quality (Fig. 2b). We interpret this to result from both a low natural remnant magnetisation (NRM) intensity (typically between 10 and $50 \mathrm{~A} \mathrm{~m}^{-2}$ ) and the likely growth of iron sulfides during the $\sim 50$-year storage of the cores, which are probably the cause of magnetic noise as well as the partial isolation of the characteristic component in some samples (Fig. S1, Table S1). Due to the low quality of results, we are cautious and are only confident in those magnetozones with at least three adjacent samples sharing similar polarity values. Cores 23 to 19 express a well-defined polarity pattern. Below, the interval encompassing cores $26-28$ (269.12-214.43 m b.s.f.; shown in grey in Fig. 2b) does not show a definite pattern and, consequently, was not considered for palaeomagnetic correlation. The lower part, cores $35-43$, has a very low recovery and is prone to normal polarity directions. Magnetostratigraphic results for the upper Oligocene generally agree with those recently published by Jovane et al. (2020), as shown in Fig. 2. For the lower part of the record, our biostratigraphic results provide new tie points that indicate a lower-Oligocene age, instead of the previously published upper-Eocene age (Hayes et al., 1975; Jovane et al., 2020).

The presence of the marker dinocyst Malvinia escutiana $(\mathrm{FO}=33.7 \mathrm{Ma}$; Houben et al., 2011, 2019) in the lowermost sediment sample (Core 43, $404.66 \mathrm{~m}$ b.s.f.), directly overlying the basement, indicates an early-Oligocene age of the lowermost sediment that was also suggested from the age of the underlying ocean crust (Cande et al., 2000). Thus, we correlated the normal magnetozone in Core 43 (400.7 m b.s.f.) with magnetic chron C13n. A few sections above, we find the FO of Stoveracysta ornata (32.5 Ma) at $396.62 \mathrm{~m}$ b.s.f., the FO of Operculodinium eirikianum $(31.56 \mathrm{Ma})$ at $352.78 \mathrm{~m}$ b.s.f., the FO of Corrudinium labradori $(30.92 \mathrm{Ma})$ at $362.42 \mathrm{mb}$.s.f., and the $\mathrm{LO}$ of Stoveracysta ornata $(30.8 \mathrm{Ma})$ at $323.6 \mathrm{~m}$ b.s.f. Thus, we suggest that the reversal in the lower part of Core 34 (321.2 mb.s.f.) is correlated with the top of C11n.1n $(29.18 \mathrm{Ma})$ and that the normal magnetozone found in cores 29 and 30 ( 277 m b.s.f.) is correlated with chron C9n (Table 2). Core 21 ( $\sim 190.8 \mathrm{~m}$ b.s.f.) contains one isolated calcareous nannofossil horizon (Burns, 1975) dominated by Chiasmolithus altus, which marks the oldest age of $25.44 \mathrm{Ma}$ 
Table 1. List of palynomorphs and their abbreviated codes found in the CA plot (Fig. 5). Assumed in situ and reworked dinoflagellate cyst taxa are assigned to protoperidinioid (P-cyst) taxa and gonyaulacoid (G-cyst) taxa. "indet." denotes indeterminate.

\begin{tabular}{|c|c|c|c|}
\hline In situ protoperidinioid taxa & Code & In situ gonyaulacoid taxa & Code \\
\hline Brigantedinium pynei & Br pyn & Achomosphaera alcicornu & Ac alc \\
\hline Brigantedinium simplex & $\mathrm{Br} \operatorname{sim}$ & Batiacasphaera spp. (pars) & Ba spp \\
\hline Brigantedinium spp. (pars) & Br spp & Batiacasphaera cooperi & Ba coo \\
\hline Lejeunecysta spp. (pars) & L spp & Batiacasphaera compta & Ba com \\
\hline Lejeunecysta acuminata & $\mathrm{L} \mathrm{acu}$ & Batiacasphaera sp. B sensu Bijl et al. (2018a) & Ba spB \\
\hline Lejeunecysta adeliensis & $\mathrm{L}$ ade & Cerebrocysta spp. & Cer spp \\
\hline Lejeunecysta attenuata & $\mathrm{L}$ att & Cleistosphaeridium sp. A. sensu Bijl et al. (2018a) & $\mathrm{Cl} \mathrm{spA}$ \\
\hline Lejeunecysta fallax & L fal & Corrudinium spp. (pars) & Co spp \\
\hline Lejeunecysta katatonos & L kat & Corrudinium labradori & Co lab \\
\hline Lejeunecysta rotunda & $\mathrm{L}$ rot & Gelatia inflata & $\mathrm{G} \inf$ \\
\hline Lejeunecysta sp. A & L spA & Hystrichokolpoma bullatum & Hy bul \\
\hline Malvinia escutiana & $M$ esc & Impagidinium cf. aculeatum & I acu \\
\hline Protoperidinium indet. & Prot & Impagidinium cantabrigiense & I can \\
\hline Selenopemphix antarctica & Se ant & Impagidinium velorum & I vel \\
\hline Selenopemphix brinkhusii & Se bri & Impagidinium victorium & I vic \\
\hline Selenopemphix nephroides & Se nep & Impagidinium paradoxum & I par \\
\hline Selenopemphix spp. (pars) & Se spp & Impagidinium pallidum & I pal \\
\hline Dinocyst sp. 1 & Dino sp1 & Impagidinium sp. A sensu Bijl et al. (2018a) & I spA \\
\hline Reworked peridinioid cysts & & Nematosphaeropsis labyrinthus & $\mathrm{N}$ lab \\
\hline Alterbidinium distinctum & $\mathrm{Al}$ dis & Operculodinium sp. A sensu Bijl et al. (2018a) & O spA \\
\hline Deflandrea spp. (pars) & Df spp & Operculodinium centrocarpum & $\mathrm{O}$ cen \\
\hline Moria zachosii & M zac & Operculodinium eirikianum & O eir \\
\hline Phthanoperidinium spp. (pars) & Ph spp & Operculodinium janduchenei & O jan \\
\hline Senegalinium spp. & Sen spp & Operculodinium piaseckii & O pia \\
\hline Spinidinium spp. (pars) & Spd spp & Operculodinium spp. (pars) & O spp \\
\hline Vozzhennikovia spp. (pars) & Voz spp & Pyxidinopsis spp. & Pyx spp \\
\hline \multirow[t]{10}{*}{ Other P-cyst reworked } & otr-P & Spiniferites ramous & Sf ram \\
\hline & & Spiniferites bulloideus & Sf bul \\
\hline & & Spiniferites spp. (pars) & Sf spp \\
\hline & & Stoveracysta kakanuiensis & St kak \\
\hline & & Stoveracysta ornata & St orn \\
\hline & & Reworked gonyaulacoid cysts & \\
\hline & & Arachnodinium antarcticum & A ant \\
\hline & & Cerebrocysta spp. (pars) RW & Cer RW \\
\hline & & Corrudinium regulare & Co reg \\
\hline & & Corrudinium incompositum & Co inc \\
\hline Other palynomorphs & & Enneadocysta spp. (pars) & Enn spp \\
\hline Unidentified dinocyst 1 & Indet 1 & Hystrichokolpoma rigaudiae & H rig \\
\hline Unidentified dinocyst 2 & Indet 2 & Hystrichosphaeridium truswelliae & Hy tru \\
\hline Unidentified dinocyst 3 & Indet 3 & Impagidinium spp. (pars) RW & I RW \\
\hline Terrestrial & Terr & Operculodinium spp. RW & Ope RW \\
\hline Pterospermella/green algae & Ptero & Pentadinium laticinctum & P lat \\
\hline Acritarch spp. & Acrit spp & Thalassiphora pelagica & Th pel \\
\hline Acritarch chorate/spiney spp. & Acri spiney & Tuberculodinium vancampoae & $\mathrm{T}$ van \\
\hline Leiosphaeridia & Leios & Turbiosphaera spp. (pars) RW & Tur spp \\
\hline Cymatosphaera spp. (pars) & Cym Spp & Other G-cyst reworked & otr-G \\
\hline
\end{tabular}


Table 2. Improved age model for the Oligocene of DSDP Site 274 determined by dinocysts biostratigraphy indicators (FO denotes first occurrence, and LO denotes last occurrence) and palaeomagnetic reversals (chrons).

\begin{tabular}{lllrrrl}
\hline FO/LO & Genus/Chron & Species & Age (Ma) & Depth (m b.s.f.) & Depth error & Event source \\
\hline & Base of C7n.2n & & 24.474 & 199.47 & & This study \\
& Base of C9n & & 27.44 & 277 & & This study \\
& Top of C11n.1n & & 29.18 & 321.2 & & This study \\
LO & Stoveracysta & ornata & 30.8 & 323.655 & 2.015 & This study \\
FO & Corrudinium & labradori & 30.92 & 362.42 & 1.24 & This study \\
& Base of C12n & & 31.03 & 363.44 & & This study \\
FO & Stoveracysta & ornata & 32.5 & 396.62 & 5.25 & This study \\
& Base of C13n & & 33.7 & 400.17 & & This study \\
FO & Malvinia & escutiana & 33.7 & 404.66 & & This study \\
\hline
\end{tabular}

(chron C8n; Gradstein et al., 2012). Cores 34-20 are included in the diatom Pyxilla Prolungata zone (Hayes et al., 1975), which also suggests an early-Oligocene age ( $>25 \mathrm{Ma})$; however, the LO of Pyxilla Prolungata is thought to go on until the Oligocene-Miocene boundary (23 Ma) (Gombos, 1977). Based on these initial reported biostratigraphic observations (Hayes et al., 1975), we correlate the base of the normal magnetozone of Core 21 (199.47 m b.s.f.) with the base of chron C7n.2n (24.4 Ma). A few biostratigraphic constraints, including middle-Miocene radiolarian species in Core 19 (Hayes et al., 1975), indicate that the latest Oligocene and OligoceneMiocene transition is missing in a large hiatus of $\sim 7 \mathrm{Myr}$ between cores 19 and 20 (181.23 m b.s.f.). We abstain from correlating the normal magnetozone of Core 19 to a specific chron, due to the limited biostratigraphic markers; thus, we support Jovane et al. (2020), who suggested Langhian to Burdigalian ages. Extrapolating linearly between chronoand biostratigraphic tie points (Fig. 2b, Table 2), we calculate the average sedimentation rate in the Oligocene to be $2.4 \mathrm{~cm} \mathrm{kyr}^{-1}$.

\subsection{Lipid biomarkers}

A total of 39 of the 42 samples processed for lipid biomarkers showed no indication of overprints by biassing indices (Fig. S2). The low BIT index value $(<0.08$, with one exception at 361 m b.s.f.; Fig. S2) suggests low terrestrial organic material influence, relative to marine GDGT production. The normal Ring index values (Fig. S3), with only two outliers, suggest normal pelagic contributions to the sedimentary GDGTs. Thus, overall, TEX 86 values represent an in situ pelagic SST signal. Moreover, the absence of co-variance between $\mathrm{TEX}_{86}$ and indices for overprint suggest that the high variability in $\mathrm{TEX}_{86}$ also represents a pelagic signal. $\mathrm{TEX}_{86}$ values range from 0.44 to 0.55 . Using the linear calibration of Kim et al. (2010) (Fig. 4c), SSTs vary between 10 and $17^{\circ} \mathrm{C}\left( \pm 5.2^{\circ} \mathrm{C}\right)$ throughout the record, with noticeable variability. Below $342 \mathrm{~m}$ b.s.f., reconstructed SSTs are relatively high and variable $\left(10-16^{\circ} \mathrm{C}\right)$. Between 335 and $248 \mathrm{~m}$ b.s.f., SSTs are lower and display lower variability $\left(10-13^{\circ} \mathrm{C}\right)$ at the same sample resolution as above. An increase in SST of $\sim 6^{\circ} \mathrm{C}$ at $248 \mathrm{~m}$ b.s.f. marks the onset of a second interval with high variability in SST.

\subsection{Palynomorphs and dinocyst assemblages}

A total of 43 of the 50 samples analysed contain sufficient dinocysts. All samples that were too low in dinocysts came from the top of the studied record (186.66-155.68 m b.s.f.) and were discarded. Samples showed a varying abundance of four palynomorph groups: reworked dinocysts, in situ dinocysts, terrestrial palynomorphs, and acritarchs and prasinophytes (Fig. 4a). The sediments below $352.5 \mathrm{~m}$ b.s.f. are dominated by reworked dinocysts, which decrease in abundance above this depth. From $352.5 \mathrm{~m}$ b.s.f. to the top of the record, in situ dinocysts constitute the most abundant palynomorph group, followed by acritarchs, which slightly increase up-core. Pollen and spores remain low throughout the entire record $(<6 \%)$. Furthermore, our palynological samples contain a varying amount of pyritised microfossils and amorphous organic material.

\subsubsection{Dinocyst taxonomy}

Identification of dinocysts on a species level was possible in most cases (Table S3). However, some dinocysts were only defined on a genus level when distinctive features were lacking. Brigantedinium spp. includes all round brown specimens. Batiacasphaera spp. includes small sub-spherical cysts with an angular, likely apical archeopyle and, if any, minute surface ornamentation. Pyxidinopsis spp. has similar features to Batiacasphaera spp. but is typically (even) smaller, has a thicker, slightly darker wall, and is less folded with a single plate precingular archeopyle. Dinocysts with a smooth, spherical, psilate, hyaline wall and a free, angularrounded operculum (five to six sides) generally found within the cyst are hereby informally named "Dinocyst sp. 1". The saphopylic archeopyle of Dinocyst sp. 1 resembles that of Brigantedinium spp. and Protoperidinium spp.; thus, we con- 
sider Dinocyst sp. 1 to belong to the (heterotrophic) protoperidinioid $(\mathrm{P})$ cysts.

\subsubsection{Reworked dinocyst assemblages}

The lowermost $60 \mathrm{~m}$ of the sediment record, below $352.5 \mathrm{~m}$ b.s.f., yields abundant and diverse dinocysts that are common in Eocene Southern Ocean sediments (Bijl et al., 2013; Cramwinckel et al., 2020; Crouch et al., 2020), including Vozzhennikovia apertura, Deflandrea antarctica, Enneadocysta spp. and Phthanoperidinium spp. These species are found throughout the entire record, but their relative abundance decreases up-section. We note good preservation of some of the more delicate dinocysts, which have known biostratigraphic ranges that predate the age of the ocean crust underneath DSDP Site 274; therefore, we still regard them to be reworked. However, we cannot rule out that these typical late-Eocene dinocysts were still present in the early Oligocene and, therefore, in situ deposited in the record (Bijl et al., 2018a).

\subsubsection{In situ dinocyst assemblages}

In the lowermost $15 \mathrm{~m}$ of the record, below $390.4 \mathrm{~m}$ b.s.f., the (apparent) in situ assemblage (Fig. 4b) is dominated by P-cyst species, Dinocyst sp. 1 and Brigantedinium spp., indicating high nutrient levels in open-ocean settings. Given that Brigantedinium spp. has a preference for open-ocean conditions, often with proximity to upwelling areas both in the modern and the ancient ocean (Zonneveld et al., 2013; Sluijs et al., 2005), we render it unlikely that it was transported from the continental shelf and reworked. Brigantedinium spp. and Dinocyst sp. 1 have not been reported from CRP-3 (Clowes et al., 2016) or the Eocene erratics (Levy and Harwood, 2000) from the Ross Sea area. The good preservation state of the delicate Dinocyst sp. 1 and Brigantedinium spp. species argues for in situ production. The extinct P-cyst species Malvinia escutiana occurs throughout the record: its relative abundance increases from the bottom of the record towards its peak interval from $224 \mathrm{~m}$ b.s.f. to the top of the record. At about $335 \mathrm{~m}$ b.s.f., the dinocyst assemblages change significantly. Above this depth, G-cysts associated with open, possibly warmer and oligotrophic waters dominate the assemblages. This shift in the dinocyst assemblage does not coincide with any remarkable change in the lithology. Hence, we are confident that the assemblage shift is a real feature in the record and not a result of the selective preservation of $\mathrm{P}$ - and G-cysts. It is known that P-cysts are more sensitive than G-cysts to oxidation (e.g. Zonneveld et al., 2010), and any mechanism (bottom currents, mixing, sediment starvation) that favours sediment oxygenation would decrease the probability of finding P-cysts preserved in the record relative to G-cysts. Batiacasphaera spp., Pyxidinopsis spp. and Cerebrocysta spp. compose the majority of the G-cysts. Spiniferites spp. is relatively abundant $(\sim 10-20 \%$ of the total in situ dinocyst counts) in the interbedded chert layers below $352.5 \mathrm{~m}$ b.s.f. and again, although less prominently, at $221.4 \mathrm{~m}$ b.s.f., whereas it remains low $(<4 \%)$ in the rest of the record. Operculodinium spp. is common (10$20 \%$ ) between 201 and $221 \mathrm{~m}$ b.s.f. The highest amount of Operculodinium spp. (27\%) was found at $239.16 \mathrm{~m}$ b.s.f. $\mathrm{Ne}$ matosphaeropsis labyrinthus is only registered between 361 and $352 \mathrm{~m}$ b.s.f. (green line in Fig. 4b). Impagidinium spp. remains low $(<7 \%)$ in all samples. Throughout the record, dinocyst species indicative of cold water are rare. Selenopemphix antarctica, a major component of the modern Antarctic coastal assemblages (Zonneveld et al., 2013), is never abundant and is only present in few samples (between 390.44 and $333 \mathrm{~m}$ b.s.f., and at $302 \mathrm{~m}$ b.s.f.). I. pallidum, a dinocyst abundant in polar areas of the modern ocean (Zonneveld et al., 2013; Marret et al., 2019) but known for its tolerance to higher temperatures in the past (de Schepper et al., 2011), has a scattered low presence throughout the record.

\subsubsection{Other palynomorphs: pollen, acritarchs and prasinophyte algae}

The consistently sparse pollen assemblages from DSDP Site 274 suggest a shrubby tundra landscape with low-growing Nothofagaceae and Podocarpaceae. The offshore and offpath location with respect to the wind patterns from the continent may be an explanation for the low pollen numbers, and we cannot make further interpretations regarding the terrestrial ecology. The relative abundance of acritarchs and prasinophytes seems to increase up-core. Transparent chorate acritarchs are the most dominant throughout the record. Leiosphaeridia spp. is only sporadically present and is most common in the lowermost sediments (>390 m b.s.f.). Prasinophyte algae Cymatiosphaera spp. is found throughout the record but is more abundant around $285 \mathrm{~m}$ b.s.f. and above $224 \mathrm{~m}$ b.s.f.

\subsection{Correspondence analysis}

The CA on our palynological results (Fig. 3, Table S4) resulted in the first two axes explaining $46 \%$ of the total variance ( $31 \%$ for axis 1 , and $15 \%$ for axis 2 ), which is high given the multidimensionality of the high dinocyst diversity. Most of the dinocysts that were assumed to be reworked a priori (purple circles in Fig. 3) show negative scores on axis $2(64 \%)$. Those taxa that do not have a negative score on axis 2 generally have low total counts or relative abundances (small circles in Fig. 3). Overall, the species that we consider to be definitely in situ (see also Bijl et al., 2018a) have negative scores on axis 1 , and reworked taxa tend to cluster on the positive side of axis 1 . Terrestrial palynomorphs (pollen and spores) plot in the same area as the reworked dinocyst taxa. The overall separation of reworked and in situ taxa on the first CA axis gives us confidence that our a priori assumption of in situ and reworked is correct (Table 1). 


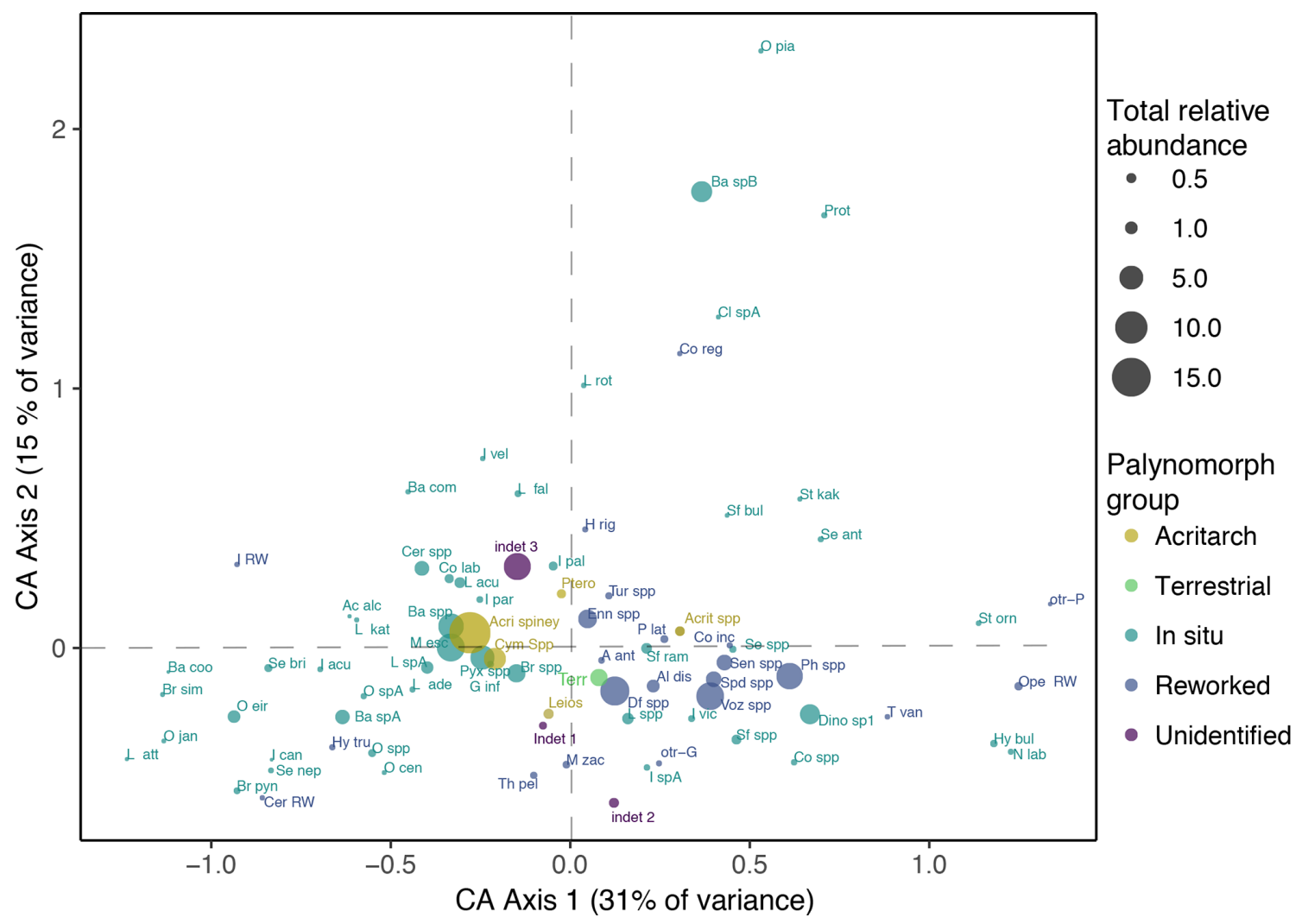

Figure 3. Correspondence analysis (CA) of the dinocyst assemblage data from DSDP Site 274. The size of the points indicates the total relative abundance of the specific species. The abbreviations of the dinocysts species can be found in Table 1. The data were plotted in the C2 software program (Juggins, 2007). The analysis scores are provided in Table S4.

\section{Discussion}

\subsection{Updated age model}

The age model for DSDP Site 274 is updated with four additional biostratigraphic datums and five magnetostratigraphic datums. Specifically, age constraints in the bottom (early Oligocene, $33.7 \mathrm{Ma}, 404.66 \mathrm{~m}$ b.s.f.) and top (late Oligocene, $24.4 \mathrm{Ma}, 181.23 \mathrm{~m}$ b.s.f.) of the studied interval (408.5-174. $2 \mathrm{~m}$ b.s.f.) have been improved. However, the few existing age constraints for the middle part (mid-Oligocene, 307.1-199.5 m b.s.f.) do not allow a significant improvement of the existing age model for this interval (Fig. 2b, Table 2). Jovane et al. (2020) presented an update of the biostratigraphic constrains of Site 274 and, afterwards, guided their magnetostratigraphic correlation with these constraints. Like ours, their polarity pattern alone is not sufficient to provide an independent chronology. Our obtained polarity pattern is similar to Jovane et al. (2020) for the upper part of our study, i.e. late Oligocene (Fig. 2b). This is also true for the unclear polarity zone between cores 29 and 25 where Jovane et al. (2020) also found inclinations that produce a uncertain polarity pattern. Our correlation with the timescale, however, differs in the lower part of the section, below $320 \mathrm{~m}$ b.s.f., where we provide new magnetostratigraphic data and biostratigraphic age constraints, and implement the most recent insights on the age of the ocean crust underlying the site (Cande et al., 2000). This results in younger ages for the lower part of the section, which are propagated upwards, altogether indicating younger ages for DSDP Site 274 compared with the study of Jovane et al. (2020) and the initial report. We acknowledge that although our new constraints have improved the age model, large uncertainties remain due to moderate recovery, reworked material, weak NRM intensities (Table S1) and the limited occurrence of age-diagnostic microfossils. This means that between tie points, sedimentation rates may vary and hiatuses could be present. Therefore, we plot the data in the depth domain and indicate the age tie points next to the depth scale (Figs. 2, 4). Notwithstanding these age model uncertainties, the proxy data that we present provide a rare glimpse into early- to middleOligocene surface-water conditions.

\subsection{Palaeotemperature and palaeoenvironment in the Oligocene at DSDP Site 274}

Combined, the temperature, in situ and reworked palynomorph results provide integrated palaeoceanographic con- 
(a) \% Palynomorphs

(b) \% Dinocyst groups

(c) TEX $_{86}-$ SST
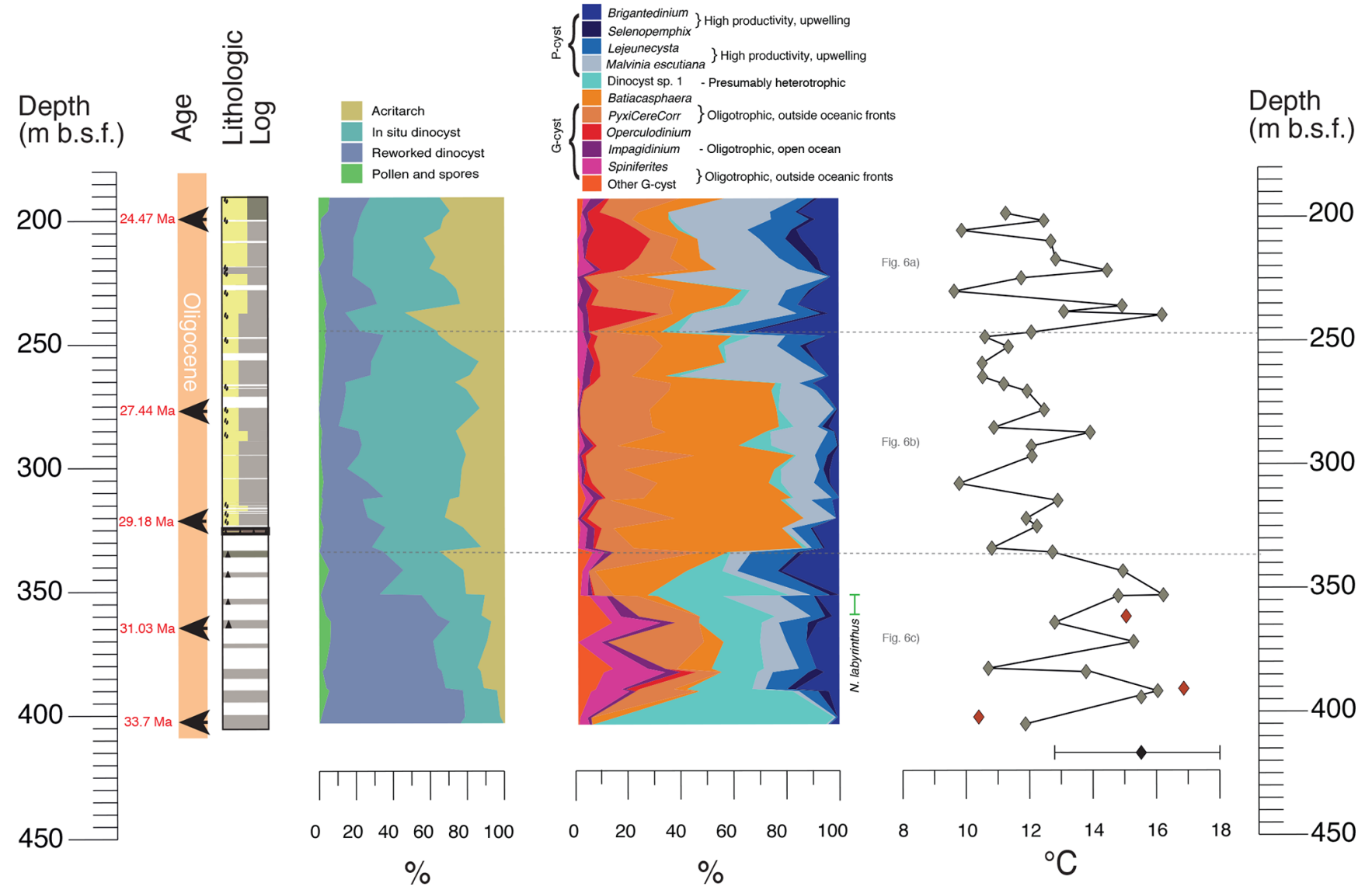

Depth (m b.s.f.)

Figure 4. Lithological (the legend is the same as Fig. 2), palynological and TEX 86 -SST results from DSDP Site 274 plotted against depth. Arrows indicate age (Ma) tie points according to the age model described in Table 2 . The dotted grey line indicates the time slices selected for Fig. 5. (a) The cumulative relative abundance of palynomorph groups. (b) The cumulative relative abundance (\%) of selected dinocyst groups recorded in the studied interval. Blue tones are P-cysts, and red-tones are G-cysts. (c) TEX $86^{-b a s e d ~ S S T s ~(l i n e a r ~ c a l i b r a t i o n ; ~ K i m ~ e t ~}$ al., 2010), calibration error is $\pm 5.2^{\circ} \mathrm{C}$, are indicated by the black bar at the bottom of the plot. The TEX 86 outliers are marked in red.

figurations offshore of the Ross Sea margin during the Oligocene (33.7-24.4 Ma) (Fig. 4). Furthermore, we combine our reconstruction with those available around the East Antarctic margin from the western Ross Sea and Wilkes Land to obtain a regional perspective.

\subsubsection{Surface oceanographic conditions}

Both dinocyst assemblages and $\mathrm{TEX}_{86}$-based SST results (Fig. 4b, c) consistently suggest temperate surface-ocean conditions. High variability in the dinocyst- and TEX $\mathrm{T}_{86}-\mathrm{SST}$ reconstructions reflects highly dynamic surface-ocean conditions. Although P-cyst species are abundant in the top and bottom of the record, suggesting nutrient-rich conditions, the middle part of the record is dominated by a high abundance of G-cyst species, indicating that oligotrophic and warm conditions prevailed (Fig. 4b). The dominance of G-cysts implies that upwelling (the proto-Antarctic Diver- gence) was greatly reduced or located far away from the site. Above $265 \mathrm{~m}$ b.s.f., the more frequent shifts between Pcyst-dominated and G-cyst-dominated assemblages reflects strongly varying oceanographic conditions, perhaps as a result of shifting frontal system locations or dynamics (as offshore of Wilkes Land; Salabarnada et al., 2018; Bijl et al., 2018b; Hartman et al., 2018). The scarce presence of typical sea-ice-affiliated dinocysts suggests that sea ice was absent or that the sea ice seasonal coverage was strongly reduced (Bijl et al., 2018b) compared with the present day (Fetterer et al., 2020). The dinocyst assemblages mostly contain known marine species, indicative of normal ocean salinities. However, Dinocyst sp. 1 (turquoise in Fig. 4b), abundant in sediments at $>335 \mathrm{~m}$ b.s.f., morphologically resembles the peridinioid Senegalinium spp., a genus known for its high tolerance to low surface-water salinities (Sluijs and Brinkhuis, 2009). If morphology is indicative of environmental conditions, the region could have been under the influence 
of meltwater and/or increased precipitation during the early Oligocene. The overall abundance of reworked (Eocene) dinocysts suggests the erosion of marine sediments on the Ross Sea continental shelf and the transport thereof towards the abyssal plain by wind-driven transport of surface water or through density-driven bottom water flow cascading down the continental slope. In general, the Oligocene dinocyst assemblages found at DSDP Site 274 are similar to present-day dinocyst assemblages living between the subantarctic and subtropical front, where temperatures range from 0 to $15^{\circ} \mathrm{C}$ (Prebble et al., 2013). This is in line with the high TEX $_{86}$ SSTs $\left(10-17^{\circ} \mathrm{C}\right)$ and indicates much warmer surface waters with lower nutrient levels than today, although the site is currently located in an area with average SSTs $\sim-1{ }^{\circ} \mathrm{C}$ (Locarnini et al., 2019).

\subsubsection{Oligocene oceanography and climate evolution at DSDP Site 274 in a regional context}

The generally warm SSTs throughout the Oligocene suggest that the recorded high productivity at the site was probably not the result of cold upwelled waters. However, in the early Oligocene (404.66-335.34 m b.s.f.), the relatively abundant P-cysts do indicate high-nutrient and, possibly, low-salinity surface-water conditions (Fig. 4b). Instead of upwelling, we suggest that strong surface-water mixing stimulated ocean primary productivity at the site, perhaps with additional nutrient sources through melting from the Ross Sea continental margin. Rifting of the western Ross Sea shelf since $60 \mathrm{Ma}$ (Huerta and Harry, 2007) has created thick Eocene sedimentary successions on the Ross Sea shelf. Glacial isostatic adjustments as a response to the Antarctic ice sheet buildup ( $\sim 48-34 \mathrm{Ma})$ caused reorganisation of shelf sedimentation (Stocchi et al., 2013), notably increases in sedimentation rates due to the accumulation space created by higher sea level and bedrock subsidence in some regions and erosion due to bedrock uplift at others. Strata drilled at DSDP Site 270 on the Ross Sea continental shelf indicate periods of early-Oligocene glaciomarine deposition derived from local ice caps nucleated on elevated highs prior to tectonic subsidence in that region (De Santis 1999; Kulhanek et al., 2019). Turbid meltwater derived from the margins of these marineterminating ice caps and from glaciomarine/fluvial systems at the margins of outlet glacier along the Transantarctic Mountain front (Fielding et al., 2000) would also allow for transport via a suspended sediment load or downslope processes towards the continental rise at DSDP Site 274, similar to the Wilkes Land continental rise (Bijl et al., 2018b; Salabarnada et al., 2018). The high abundance of reworked late-Eocene dinocysts testifies to the influence of continentalshelf-derived surface water towards the site, which brings nutrients and promotes productivity (increase in $\mathrm{P}$ cysts). This high amount of reworked dinocysts could further argue for a reworked TEX ${ }_{86}$-SST signal. However, the nearshore character of the Eocene reworking (abundant pro- deltaic, marginal-marine peridinioid cysts) would have increased the branched, soil-derived GDGTs. This sharply contradicts the low $(<0.08)$ BIT values (Fig. S2). After $\sim 29 \mathrm{Ma}$ (335 m b.s.f.), the relatively high $\mathrm{TEX}_{86}$-based SSTs (10$17^{\circ} \mathrm{C}$ ) and abundant offshore, temperate dinocyst species Operculodinium spp., Spiniferites spp. and Nematosphaeropsis labyrinthus (Fig. 5b, c) indicate a long period of temperate conditions at DSDP Site 274. The co-varying trend between dinocyst species and the SSTs indicates that SST has a strong influence on the biotic response.

For the first time, Malvinia escutiana is found in midOligocene sediment ( $<265 \mathrm{~m}$ b.s.f.); this extends the LO of this species relative to previous reports (Bijl et al., 2018a). Its high abundance suggests that conditions were favourable for this species and makes it unlikely that its occurrence in the mid-Oligocene represents a reworked signal. The CA plot (Fig. 3) shows that Malvinia escutiana co-varies with oligotrophic and temperate dinocyst groups as well as with acritarchs. This suggests that Malvinia favours open-water and low-nutrient conditions. A conundrum in our data is the increase in G-cyst groups, Batiacasphaera spp., Pyxidinopsis spp. and Cerebrocysta spp., in the mid-Oligocene and the decrease in P-cyst abundances synchronous with declining SST starting at $\sim 29 \mathrm{Ma}(335.3 \mathrm{~m}$ b.s.f.). At present, these G-cysts are associated with more northerly subantarctic and subtropical front zone regions (Prebble et al., 2013) with temperate ocean conditions. Although temperate dinocyst and lipid biomarker signals are generally consistent in the record, an increase in G-cyst assemblages affiliated with warm conditions corresponds to a decrease in SST between $\sim 29$ and $26.8 \mathrm{Ma}$ (335.3-252.2 m b.s.f.). Here, we argue that decreasing nutrient levels cause P-cyst to be replaced by Gcysts. Throughout the record, variability in nutrient conditions rather than temperature seems to be the driving factor in dinocyst distribution.

Abundance of transparent chorate acritarchs at DSDP Site 274 generally follows warmer SSTs, similarly to what was found in the record of Site U1356 offshore of Wilkes Land (Bijl et al., 2018b). The CA analysis showed little covariance between acritarchs and reworked cysts, suggesting that the acritarchs are in situ. At $\sim 26.5 \mathrm{Ma}(239.2 \mathrm{~m}$ b.s.f.), the acritarchs peak is synchronous with a peak in temperate dinocyst species (Operculodinium spp.). Acritarchs as well as Operculodinium spp., a pioneer species, are known to be opportunist (e.g. Dale, 1996). Previous studies on Antarcticproximal records, from the CIROS-1 core (Hannah, 1997) and DSDP Site 270 (Kulhanek et al., 2019), have associated the presence of acritarchs (Leiosphaeridia spp.) and prasinophytes (Cymatiosphaera spp.) with episodes of sea ice melting. We did not find abundant Leiosphaeridia spp. Thus, we interpret that the meltwater influence was reduced at DSDP Site 274, compared with sites on the Ross Sea continental shelf that were more proximal to the glaciated margin. 

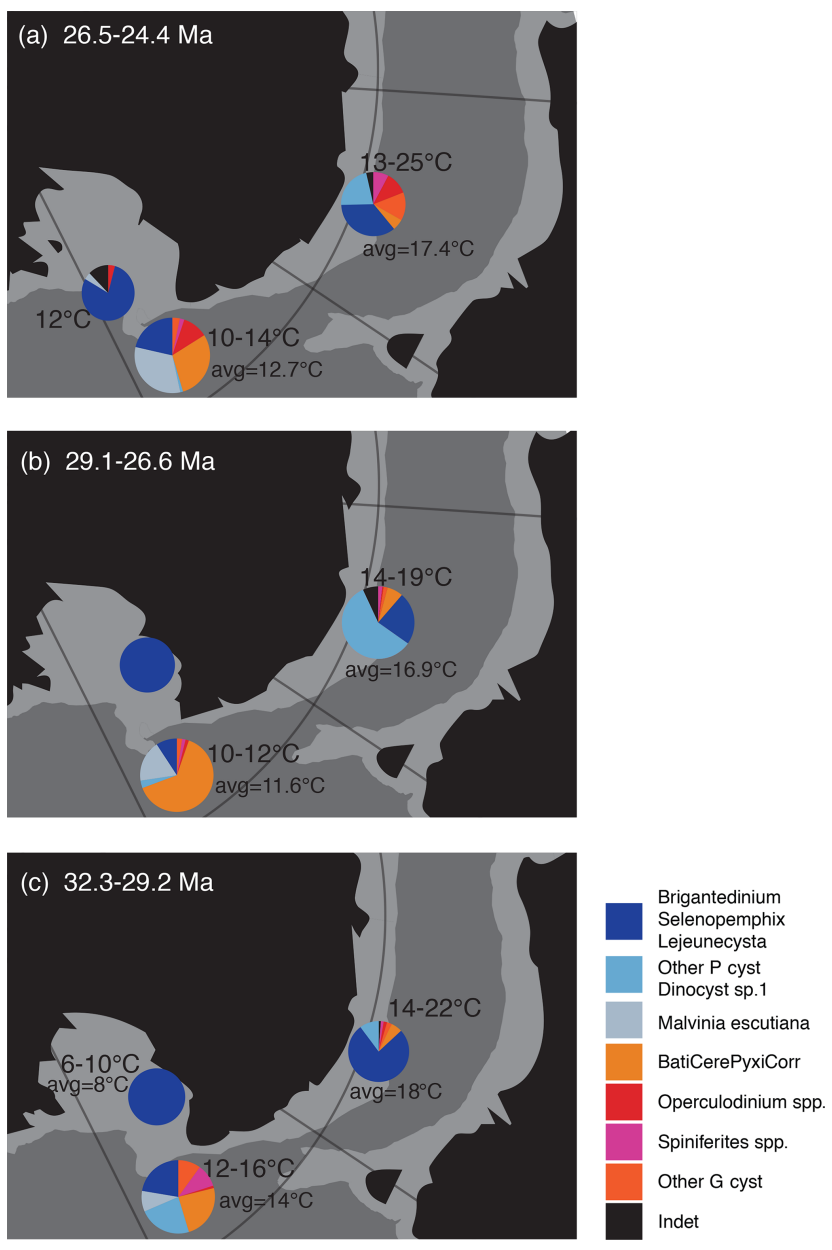

Figure 5. Synthesis of sea surface temperature and dinocyst assemblage changes between the early (c), mid (b) and late Oligocene (a) in the Ross Sea (CRP, DSDP Site 270), offshore of Cape Adare (this study, DSDP Site 274) and Wilkes Land margin (Site U1356). The pie charts visualise the dinocyst assemblage composition at the respective sites (see legend). Dinocyst assemblage data from the Wilkes Land margin, U1356, are from Bijl et al. (2018a, b) for panels (a)-(c). Dinocyst assemblage data from the Ross Sea are gathered from DSDP Site 270 (Kulhanek et al., 2019) for panel (a) and from CRP (Houben et al., 2013; Clowes et al., 2016) for panels (b) and (c). The TEX 86 -SST data from Wilkes Land, U1356, are from Hartman et al. (2018), and $35 \mathrm{TEX}_{86}$-data points were used: 7 in panel (a), 9 in panel (b) and 19 in panel (c). In the Ross Sea, there is a lack of TEX $_{86}-\mathrm{SST}$ data from the midOligocene, but Duncan (2017) presented unpublished TEX 86 data from CIROS-1 (12 $\mathrm{TEX}_{86}$-data points), here displayed in panel (c), and from DSDP Site 270, where only one data point matched our mid-early-Oligocene time slice in panel (a). All TEX $_{86}$ data have been converted to SST using the linear calibration method of Kim et al. (2010) (calibration error of $\pm 5.2^{\circ} \mathrm{C}$ ). The palaeogeographic position is generated with GPlates (http://www.gplates.org, last access: 13 June 2016), based on the global plates geodynamic motion model from Müller et al. (2018).

\subsection{Regional perspective}

We compare our Oligocene palaeoceanographic reconstructions from DSDP Site 274 with records from off the Wilkes Land margin (Site U1356; Hartman et al., 2018; Salabarnada et al., 2018; Bijl et al., 2018a, b; Sangiorgi et al., 2018) and the Ross Sea (Houben et al., 2013; Clowes et al., 2016; Kulhanek et al., 2019; Duncan, 2017) (Fig. 5). For this comparison, published $\mathrm{TEX}_{86}$ data from the Wilkes Land margin (Hartman et al., 2018) and the Ross Sea (Duncan, 2017) were converted to SSTs using the linear calibration of Kim et al. (2010) (calibration error of $\pm 5.2{ }^{\circ} \mathrm{C}$ ).

\section{Early Oligocene (32.3-29.2 Ma, 391-335 m b.s.f.)}

DSDP Site 274 TEX $_{86}$-SST results suggest a slightly lower average offshore temperature in the Ross Sea $\left(\sim 4^{\circ} \mathrm{C}\right)$ than at Wilkes Land (Site U1356) but higher temperatures $\left(\sim 6^{\circ} \mathrm{C}\right)$ than at the ice-proximal Ross Sea site (CIROS-1; Fig. 5c). This observation is consistent with the position of DSDP Site 274, which was at higher palaeo-latitudes compared with Site U1356 but at lower latitudes and offshore of the iceproximal sites within the Ross Sea. Indeed, evidence from the CRP cores in the Ross Sea showed that continental-scale ice sheets first expanded towards the Ross Sea around 32.8 Ma (Galeotti et al., 2016). Prior to $31 \mathrm{Ma}$ (350 m b.s.f.), the SST record from DSDP Site 274 shows some of its highest temperatures, while SSTs at Site U1356 decrease. One important consideration is whether these sites in the Ross Sea and Wilkes Land can be compared in the context of belonging to a latitudinal transect, given that they are separated by an evolving Tasmanian Gateway, which is a conduit that separates the eastern Indian and southwestern Pacific oceans. Although a deep-water connection in the Tasmanian Gateway was established in the Oligocene, the passageway was still restricted (Stickley et al., 2004; Bijl et al., 2013). Studies of the palaeo-bathymetry and sedimentary mechanisms in the Southern Ocean through the Cenozoic (e.g. Scher et al., 2015; Hochmuth et al., 2020) show the Tasmanian Gateway as well as the Pacific sector of the Southern Ocean deepen between 34 and $27 \mathrm{Ma}$, allowing easier throughflow and exchange between the different ocean sectors. The limited covariability of the Adare Basin and Wilkes Land margin, as well as different SSTs might signal a disconnect between the two sites, perhaps due to a still restricted Tasmanian Gateway. While synchronous SST variability and changes therein between the sectors after $31 \mathrm{Ma}$ suggest a connection between the ocean basins, which is in line with other studies (Scher et al., 2015), a SST difference between both sectors remains. The abundance of low-nutrient/temperate-affiliated dinocyst taxa (G-cyst) is higher at DSDP Site 274 than at the Wilkes Land margin and within the Ross Sea continental shelf, implying that nutrient input was lower at the offshore Ross Sea location than at more proximal sites, with a higher degree of meltwater input. 
Latest early Oligocene to earliest late Oligocene: "mid-Oligocene" (29.1-26.6 Ma, 333.6-239 m b.s.f.)

In the "mid-Oligocene", the disparity with respect to absolute SST average values between DSDP Site 274, the Ross Sea and the Wilkes Land margin is the strongest. Both the Wilkes Land margin and the Ross Sea have a high P-cyst content (Fig. 5b). Palynomorphs from Ross Sea shelf deposits from the Oligocene, dominated by Lejeunecysta spp. and brackish water prasinophyte Cymatiosphaera (CRP: Prebble et al., 2006; Clowes et al., 2016), suggest meltwater input in the Ross Sea region through this time interval (Prebble et al., 2006). In contrast, our dinocyst assemblages suggest pelagic, low-nutrient, marine conditions, while the low numbers of terrestrial palynomorphs point to limited freshwater or meltwater input at DSDP Site 274. Similar to the Wilkes Land margin SST record, DSDP Site 274 SSTs decrease towards the late Oligocene.

\section{Late Oligocene (26.5 to 24.4 Ma, 239-192.7 m b.s.f.)}

The average TEX $_{86}$-based SST results (Fig. 5a) for IODP Site U1356 and DSDP Site 274 show large $\left(>6^{\circ} \mathrm{C}\right)$ temperature variability (Hartman et al., 2018). At DSDP Site 274, we can exclude the known non-thermal biases as the cause of the strong variability (Fig. S2); therefore, we also note stronger SST variability in the late Oligocene. It is noteworthy that we see a temperature peak at DSDP Site 274 at the beginning of this interval at $26.5 \mathrm{Ma}$ ( $239 \mathrm{~m}$ b.s.f.) which is similar to what was reconstructed at the Wilkes Land margin (Hartman et al., 2018). This temperature peak coincides with a rapid decrease in the $\delta^{18} \mathrm{O}$ isotope records that may be linked to the deglaciation of large parts of the Antarctic ice sheet following a large transient glaciation centred on $\sim 26.8 \mathrm{Ma}$ (Pälike et al., 2006). The increase in the abundance of Operculodinium spp. at all three sites (DSDP sites 270 and 274, and IODP Site U1356) is a testament to the temperate conditions and/or lower nutrient availability at the time. The DSDP Site 274 sediment record is virtually barren of palynomorphs $<192.7 \mathrm{~m}$ b.s.f. $(\sim 24.4 \mathrm{Ma}), 11.7 \mathrm{~m}$ below the hiatus ( $181 \mathrm{~m}$ b.s.f.) in the record, with the sediments above estimated to be of middle-Miocene age (Hayes et al., 1975). As our SST reconstructions exclude continuous sea ice cover as a possible explanation, we interpret that oxic degradation consumed palynomorphs at the sea floor. Three reasons for increased oxygen delivery at the sea floor are proposed. The first explanation is that strengthening of the Antarctic Circumpolar Current (ACC) increased deep ventilation. This is unlikely given that the ocean frontal systems would have moved progressively northward while the Tasmanian Gateway widened, which would also have displaced the ACC flow northwards, away from the site. The second explanation is that winnowing ocean bottom currents and decreased sedimentation rates could have caused the oxic conditions that we propose and were the reason behind the disappear- ance of dinocysts. However, winnowing would not have only eroded palynomorphs and would have resulted in the coarsening of sediments, which we do not see. The lithology of the $192.7-181 \mathrm{~m}$ b.s.f. interval, where dinocyst are barren, is diatom-rich silty-clay. Decreased sedimentation rates would have prolonged the oxygen exposure time of palynomorphs once at the sea floor. Although our age model has limitations, a decrease in sedimentation rates (to $1.8 \mathrm{~cm} \mathrm{kyr}^{-1}$ ) is observed above $192.7 \mathrm{mb}$.s.f. The final explanation is that bottom water formation on the Ross Sea continental margin delivered increased oxygen-rich bottom waters to the site. Heightened obliquity sensitivity has been interpreted to be associated with enhanced oceanic-influence mass balance controls on marine-terminating ice sheets, with limited sea ice extent (Levy et al., 2019). Levy et al. (2019) interpreted a prominent increase in the sensitivity of benthic oxygen isotope variations to obliquity forcing (termed "obliquity sensitivity") between 24.5 and $24 \mathrm{Ma}$, synchronous with the first occurrence of ice-proximal glaciomarine sediments at DSDP Site 270, disconformities in CRP-2/2A and a large turnover in Southern Ocean phytoplankton. The major expansion of the ice sheet close to the Oligocene-Miocene boundary in the Ross Sea (Levy et al., 2019; Kulhanek et al., 2019; Evangelinos et al., 2021) argues in favour of Ross Sea bottom water strengthening, leading to the slowdown of the sedimentation rates above $192.7 \mathrm{~m}$ b.s.f. and the formation of the $>7 \mathrm{Myr}$ duration hiatus at $\sim 181 \mathrm{~m}$ b.s.f.

\subsection{Implications for ice-proximal conditions, hydrology and ice sheets: a hypothesis}

Warm and generally oligotrophic conditions relatively proximal to the Antarctic margin during the Oligocene imply that the Southern Ocean oceanography was fundamentally different from modern conditions (e.g. Deppeler and Davidson, 2017). Although our data suggest that ocean conditions were colder inshore than further offshore, they remain warm considering their proximity to marine-terminating outlet glaciers and ice caps in the Ross Sea area (De Santis et al., 1999; Galeotti et al., 2016; Levy et al., 2019; Kulhanek et al., 2019; Evangelinos et al., 2021). Levy et al. (2019) provided a model for ice-proximal to ice-distal oceanographic conditions in the Ross Sea during the Oligocene. In that model, Transantarctic Mountain outlet glaciers draining the EAIS, or local marine-terminating ice caps in the Ross Sea, were particularly affected by the wind-driven southward advection of warmer subsurface waters onto the Ross Sea shelf, similar to how Circumpolar Deep Water is being transported onto some regions of the continental shelf today (e.g. Wouters et al., 2015; Shen et al., 2018). The subsurface waters in that conceptual model were indicated as being warmer than the overlying low-salinity surface waters derived from glacial melts during glacial maxima, but this stratification is broken down during interglacials. The sample resolution of our dataset is too low to capture the full amplitude of orbital vari- 
ability. However, as each $2 \mathrm{~cm}$ sample represents 800 years, the variability that we see in our record could be the result of strong environmental variability on orbital timescales. Hence, the high variability in our data supports the interpretation of Levy et al. (2019), with temperate surface waters at DSDP Site 274 on the continental rise of the Ross Sea margin suggesting a well-mixed water column, as it would be difficult to envisage intermediate waters warmer than the surface waters. In this scenario, colder stratified surface water due to (sea ice) melting would be largely restricted to the coastal Ross Sea sites of DSDP Site 270, CRP and CIROS-1. Temperate surface waters offshore of the Ross Sea shelf would provide a source of heat that limits the advance of marineterminating glacial systems into the Ross Sea and Wilkes Land continental shelves. Pollen assemblages and high SSTs at DSDP Site 274, supported by terrestrial palynomorphs found at CRP-2 (Askin and Raine, 2000), suggest that the climate was warm enough to allow atmospheric melt to be the dominant control on the ice mass balance and a potential driver of deglaciation during warm orbital configurations. In addition, the warm ocean could have promoted an intensification of the hydrological cycle and consequent moisture delivery to the Antarctic hinterland, similar to what has been hypothesised for the Miocene Climatic Optimum (Feakins et al., 2012). Enhanced intense precipitation in the Antarctic hinterland would favour ice accumulation during cold orbital states to sustain a marine termination for the predominately terrestrial ice sheets. In an early- to mid-Oligocene climate that was warmer than present, precipitation and glaciation on the hinterlands could be further promoted by high elevation and a larger Antarctic landmass size (Paxman et al., 2019). Indeed, general circulation models (GCMs) for the ice-free Eocene do suggest enhanced precipitation delivery to the Antarctic continent (e.g. Huber and Caballero, 2011; Baatsen et al., 2018). If part of the source of that precipitation was the warm Southern Ocean proximal to the ice sheet, Rayleigh distillation would be reduced, leading to relatively enriched Oligocene ice sheet $\delta^{18} \mathrm{O}$ compared with that of today and, therefore, relatively depleted sea water $\delta^{18} \mathrm{O}$. The calculation of ice volumes from benthic foraminiferal oxygen isotope records (e.g. Lear et al., 2000; Bohaty et al., 2012; Liebrand et al., 2017) does consider a variety of values for the isotopic composition of the Oligocene Antarctic ice sheet. We argue that the warm oceanographic conditions, invoking strong precipitation and, possibly, a more local source of precipitation than today (Speelman et al., 2010) would explain how $\delta^{18} \mathrm{O}$ of Antarctic ice was on the less depleted end of previous assumptions. This increases the calculated Antarctic ice mass that was installed during the EOIS (Bohaty et al., 2012) as well as the Antarctic ice volume that fluctuated over strong Oligocene orbital cycles (Liebrand et al., 2017). In the future, this idea could be further tested through higher-resolution reconstructions, $\delta \mathrm{D}$ reconstructions on plant matter, and isotope-enabled palaeoceanographic and ice sheet modelling studies. In any case, future isotope-enabled ice sheet modelling should factor in warm Southern Ocean conditions for realistic estimates of Antarctic ice volume. This may imply an even higher sensitivity of Antarctic ice sheets to orbitally forced climate variability than previously assumed, and it assigns a large role to mass balance controlled by surface melt and oceanography in ice sheet stability during past warm climates, through both hydrological and basal and surface melt processes.

\section{Conclusion}

We show that temperate $\left(\mathrm{TEX}_{86} \mathrm{SST}: 10-17^{\circ} \mathrm{C} \pm 5.2^{\circ} \mathrm{C}\right)$ and relatively oligotrophic surface ocean conditions prevailed off the Ross Sea margin during the Oligocene (33.724.4 Ma). This agrees with the warm SSTs recorded offshore of Wilkes Land and also demonstrates that warm surface waters influenced the East Antarctic Ice Sheet margin in both the Ross Sea and Wilkes Land during the Oligocene. The warm surface ocean temperatures at DSDP Site 274 and colder SST on the Ross Sea continental shelf with evidence of temporary marine termination of ice caps and glaciers demonstrate a strong inshore to offshore temperature gradient in the Ross Sea. We posit that the warm surface ocean conditions near the continental shelf break during the Oligocene may have promoted increased heat delivery and precipitation transport towards the Antarctic hinterlands that lead to highly dynamic terrestrial ice sheet volumes in the warmer climate state of the Oligocene. During cold orbital phases, enhanced precipitation may have sustained high ice flux and the advance of terrestrial ice sheets and ice caps into shallow marine settings. During warm orbital configurations of the Oligocene, the heat delivery may have resulted in widespread surface melt and retreat of the terrestrial ice sheets into the hinterland.

Data availability. The data are available for download from the Zenodo data archive at https://doi.org/10.5281/zenodo.5036609 (Hoem et al., 2021).

Supplement. The supplement related to this article is available online at: https://doi.org/10.5194/cp-17-1423-2021-supplement.

Author contributions. PKB and FS designed the research. PKB, $\mathrm{CE}$ and DE collected the samples. CE and DE described the cores. LV collected and analysed palaeomagnetic samples. FSH processed samples for palynology and organic geochemistry, and FSH, PKB and FS interpreted the data. FSH wrote the paper with input from all authors.

Competing interests. The authors declare that they have no conflict of interest. 
Disclaimer. Publisher's note: Copernicus Publications remains neutral with regard to jurisdictional claims in published maps and institutional affiliations.

Acknowledgements. This work used Deep Sea Drilling Project archived samples and data provided and curated by the International Ocean Discovery Program and its predecessors. We thank the Paleomagnetic Laboratory CCiTUB-ICTJA CSIC for support with the palaeomagnetic analysis. We are also grateful to Natasja Welters and Giovanni Dammers for technical support at the Utrecht University GeoLab.

Financial support. This research has been supported by the NWO Polar Programme (grant no. ALW.2016.001.); the Spanish Ministry of Economy, Industry and Competitiveness (grant no. CTM2017-89711-C2-1-P/ CTM2017-89711-C2-2-P), co-funded by the European Union through FEDER funds; and the Alexander $\mathrm{S}$. Onassis Public Benefit Foundation $\mathrm{PhD}$ research grant (grant no. F ZL 016-1/2015-2016).

Review statement. This paper was edited by Yannick Donnadieu and reviewed by two anonymous referees.

\section{References}

Askin, R. and Raine, J.: Oligocene and Early Miocene terrestrial palynology of the Cape Roberts Drillhole CRP-2/2A, Victoria Land Basin, Antarctica, Terra Antartica, 7, 493-501, 2000.

Baatsen, M., von der Heydt, A. S., Huber, M., Kliphuis, M. A., Bijl, P. K., Sluijs, A., and Dijkstra, H. A.: Equilibrium state and sensitivity of the simulated middle-to-late Eocene climate, Clim. Past Discuss. [preprint], https://doi.org/10.5194/cp-2018-43, 2018.

Barrett, P. J.: Antarctic Cenozoic history from the CIROS-1 drillhole, McMurdo Sound, DSIR Publishing, Wellington, New Zealand, 245 pp., 1989.

Bijl, P. K., Schouten, S., Sluijs, A., Reichart, G.-J., Zachos, J. C., and Brinkhuis, H.: Early Palaeogene temperature evolution of the southwest Pacific Ocean, Nature, 461, 776-779, https://doi.org/10.1038/nature08399, 2009.

Bijl, P. K., Pross, J., Warnaar, J., Stickley, C. E., Huber, M., Guerstein, R., Houben, A. J., Sluijs, A., Visscher, H., and Brinkhuis, H.: Environmental forcings of Paleogene Southern Ocean dinoflagellate biogeography, Paleoceanography, 26, PA1202, https://doi.org/10.1029/2009PA001905, 2011.

Bijl, P. K., Bendle, J. A., Bohaty, S. M., Pross, J., Schouten, S., Tauxe, L., Stickley, C. E., McKay, R. M., Röhl, U., and Olney, M.: Eocene cooling linked to early flow across the Tasmanian Gateway, P. Natl. Acad. Sci. USA, 110, 9645-9650, https://doi.org/10.1073/pnas.1220872110, 2013.

Bijl, P. K., Houben, A. J., Bruls, A., Pross, J., and Sangiorgi, F.: Stratigraphic calibration of Oligocene-Miocene organic-walled dinoflagellate cysts from offshore Wilkes Land, East Antarctica, and a zonation proposal, J. Micropalaeontol., 37, 105-138, https://doi.org/10.5194/jm-37-105-2018, 2018a.
Bijl, P. K., Houben, A. J. P., Hartman, J. D., Pross, J., Salabarnada, A., Escutia, C., and Sangiorgi, F.: Paleoceanography and ice sheet variability offshore Wilkes Land, Antarctica - Part 2: Insights from Oligocene-Miocene dinoflagellate cyst assemblages, Clim. Past, 14, 1015-1033, https://doi.org/10.5194/cp-14-10152018, 2018b.

Blaga, C. I., Reichart, G.-J., Heiri, O., and Damsté, J. S. S.: Tetraether membrane lipid distributions in water-column particulate matter and sediments: a study of 47 European lakes along a north-south transect, J. Paleolimnol., 41, 523-540, https://doi.org/10.1007/s10933-008-9242-2, 2009.

Bohaty, S. M., Zachos, J. C., and Delaney, M. L.: Foraminiferal $\mathrm{Mg} / \mathrm{Ca}$ evidence for southern ocean cooling across the eoceneoligocene transition, Earth Planet. Sci. Lett., 317, 251-261, https://doi.org/10.1016/j.epsl.2011.11.037, 2012.

Burns, D. A.: Nannofossil biostratigraphy for Antarctic sediments, Initial Reports of the Deep Sea Drilling Project, vol. 28, U.S. Government Printing Office, Washington, pp. 589-598, https://doi.org/10.2973/dsdp.proc.28.115.1975, 1975.

Cande, S. C., Stock, J. M., Müller, R. D., and Ishihara, T.: Cenozoic motion between east and west Antarctica, Nature, 404, 145-150, https://doi.org/10.1038/35004501, 2000.

Church, M. J., DeLong, E. F., Ducklow, H. W., Karner, M. B., Preston, C. M., and Karl, D. M.: Abundance and distribution of planktonic Archaea and Bacteria in the waters west of the Antarctic Peninsula, Limnol. Oceanogr., 48, 1893-1902, https://doi.org/10.4319/lo.2003.48.5.1893, 2003.

Clowes, C. D., Hannah, M. J., Wilson, G. J., and Wrenn, J. H.: Marine palynostratigraphy and new species from the Cape Roberts drill-holes, Victoria land basin, Antarctica, Mar. Micropaleontol., 126, 65-84, https://doi.org/10.1016/j.marmicro.2016.06.003, 2016.

Coxall, H. K., Wilson, P. A., Pälike, H., Lear, C. H., and Backman, J.: Rapid stepwise onset of Antarctic glaciation and deeper calcite compensation in the Pacific Ocean, Nature, 433, 53-57, https://doi.org/10.1038/nature03135, 2005.

Cramwinckel, M. J., Woelders, L., Huurdeman, E. P., Peterse, F., Gallagher, S. J., Pross, J., Burgess, C. E., Reichart, G.-J., Sluijs, A., and Bijl, P. K.: Surface-circulation change in the southwest Pacific Ocean across the Middle Eocene Climatic Optimum: inferences from dinoflagellate cysts and biomarker paleothermometry, Clim. Past, 16, 1667-1689, https://doi.org/10.5194/cp-161667-2020, 2020.

Crouch, E. M., Shepherd, C., Morgans, H., Naafs, B., Dallanave, E., Phillips, A., Hollis, C., and Pancost, R.: Climatic and environmental changes across the early Eocene climatic optimum at midWaipara River, Canterbury Basin, New Zealand, Earth-Sci. Rev., 200, 102961, https://doi.org/10.1016/j.earscirev.2019.102961, 2020.

Dale, B.: Dinoflagellate cyst ecology: modeling and geological applications, Palynology: Principles and Applications, AASP Foundation, 1249-1275, 1996.

Deppeler, S. L. and Davidson, A. T.: Southern Ocean phytoplankton in a changing climate, Frontiers in Marine Science, 4, 40, https://doi.org//10.3389/fmars.2017.00040, 2017.

De Santis, L., Anderson, J. B., Brancolini, G., and Zayatz, I.: Seismic record of late Oligocene through Miocene glaciation on the central and eastern continental shelf of the Ross Sea, in Geology and Seismic Stratigraphy of the Antarctic Margin, 
Antarct. Res. Ser., vol. 68, edited by: Cooper, A. K., Barker, P. F., and Brancolini, G., AGU, Washinghton, D. C, pp. 235-260, https://doi.org/10.1029/AR068p0235, 1995.

De Santis, L., Prato, S., Brancolini, G., Lovo, M., and Torelli, L.: The Eastern Ross Sea continental shelf during the Cenozoic: implications for the West Antarctic ice sheet development, Global Planet. Change, 23, 173-196, https://doi.org/10.1016/S09218181(99)00056-9, 1999.

De Schepper, S., Fischer, E. I., Groeneveld, J., Head, M. J., and Matthiessen, J.: Deciphering the palaeoecology of Late Pliocene and Early Pleistocene dinoflagellate cysts, Palaeogeogr. Palaeocl., 309, 17-32, https://doi.org/10.1016/j.palaeo.2011.04.020, 2011.

Duncan, B.: Cenozoic Antarctic climate evolution based on molecular and isotopic biomarker reconstructions from geological archives in the Ross Sea region, unpublished PhD Thesis, Victoria University of Wellington, Wellington, New Zealand, 2017.

Egger, L. M., Bahr, A., Friedrich, O., Wilson, P. A., Norris, R. D., Van Peer, T. E., Lippert, P. C., Liebrand, D., and Pross, J.: Sea-level and surface-water change in the western North Atlantic across the Oligocene-Miocene Transition: a palynological perspective from IODP Site U1406 (Newfoundland margin), Mar. Micropaleontol., 139, 57-71, https://doi.org/10.1016/j.marmicro.2017.11.003, 2018.

Escutia, C., Brinkhuis, H., Klaus, A., and the IODP Expedition 318 Scientists: IODP Expedition 318: From Greenhouse to Icehouse at the Wilkes Land Antarctic Margin, Sci. Dril., 12, 15-23, https://doi.org/10.2204/iodp.sd.12.02.2011, 2011.

Evangelinos D., Escutia C., Etourneau, J., Hoem F., Bijl P., Boterblom W., van de Flierdt T., Valero L., Flores JA., Rodriguez-Tovar F.J., Jimenez-Espejo F.J., Salabarnada A., and López-Quirós A.: Late Oligocene-Miocene protoAntarctic Circumpolar Current dynamics off the Wilkes Land margin, East Antarctica, Global Planet. Change, 191, https://doi.org/10.1016/j.gloplacha.2020.103221, 103221, 2020.

Evangelinos, D., Escutia, C., van de Flierd, T., Valero L., Hoem, F., Bijl, P., Flores, J.A., Harwood, D.M., Etourneau J., Katharina, Kreissig, K., Nilsson-Kerri, K., Holder, L., López-Quirós, A., and Salabarnada, A.: Absence of a strong, deep-reaching Antarctic Circumpolar Current zonal flow across the Tasmanian Gateway during the Oligocene-early Miocene, Global Planet. Change, in review, 2021.

Feakins, S. J., Warny, S., and Lee, J.-E.: Hydrologic cycling over Antarctica during the middle Miocene warming, Nat. Geosci., 5, 557-560, https://doi.org/10.1038/ngeo1498, 2012.

Fetterer, F., Knowles, K., Meier, W., Savoie, M., and Windnagel, A.: Updated daily, Sea ice index, version 3, Antarctica, Boulder, Colorado USA, NSIDC: National Snow and Ice Data Center, https://doi.org/10.7265/N5K072F8, 2020.

Fielding, C. R., Naish, T. R., Woolfe, K. J., and Lavelle, M.: Facies analysis and sequence stratigraphy of CRP-2/2A, Victoria Land basin, Antarctica, Terra Antartica, 7, 323-338, 2000.

Frieling, J. and Sluijs, A.: Towards quantitative environmental reconstructions from ancient non-analogue microfossil assemblages: Ecological preferences of PaleoceneEocene dinoflagellates, Earth-Sci. Rev., 185, 956-973, https://doi.org/10.1016/j.earscirev.2018.08.014, 2018.

Galeotti, S., DeConto, R., Naish, T., Stocchi, P., Florindo, F., Pagani, M., Barrett, P., Bohaty, S. M., Lanci, L., and Pol- lard, D.: Antarctic Ice Sheet variability across the EoceneOligocene boundary climate transition, Science, 352, 76-80, https://doi.org/10.1126/science.aab0669, 2016.

Gombos Jr., A. M.: Paleogene and Neogene diatoms from the Falkland Plateau and Malvinas Outer Basin: Leg 36, Deep Sea Drilling Project, https://doi.org/10.2973/dsdp.proc.36.111.1977, 1977.

Gradstein, F. M., Ogg, J. G., Schmitz, M. D., and Ogg, G. M.: The Geologic Time Scale 2012, The Geologic Time Scale, 2, 4371144, 2012.

Granot, R., Cande, S., Stock, J., Davey, F., and Clayton, R.: Postspreading rifting in the Adare Basin, Antarctica: regional tectonic consequences, Geochem. Geophy. Geosy., 11, Q08005, https://doi.org/10.1029/2010GC003105, 2010.

Hannah, M.: Climate controlled dinoflagellate distribution in late Eocene-earliest Oligocene strata from CIROS-1 Drillhole, McMurdo Sound, Antarctica, Terra Antartica, 4, 73-78, 1997.

Hartman, J. D., Sangiorgi, F., Salabarnada, A., Peterse, F., Houben, A. J. P., Schouten, S., Brinkhuis, H., Escutia, C., and Bijl, P. K.: Paleoceanography and ice sheet variability offshore Wilkes Land, Antarctica - Part 3: Insights from Oligocene-Miocene TEX $_{86}$-based sea surface temperature reconstructions, Clim. Past, 14, 1275-1297, https://doi.org/10.5194/cp-14-1275-2018, 2018.

Hayes, D. E., Frakes, L. A, Bar, P. J, Burns, D. A., Barret, P. J., Chen, P., Kaneps, A. G, Kemp, E. M., McCollum, D. W., Piper, D. J, Wall, R. E., Webb, P .N., and Hutt, L.: Site 274, Initial Rep. Deep Sea Drill. Proj., 28, 369-433, https://doi.org/10.2973/dsdp.proc.28.110.1975, 1975.

Ho, S. L., Mollenhauer, G., Fietz, S., Martínez-Garcia, A., Lamy, F., Rueda, G., Schipper, K., Méheust, M., Rosell-Melé, A., and Stein, R.: Appraisal of $\mathrm{TEX}_{86}$ and $\mathrm{TEX}_{86} \mathrm{~L}$ thermometries in subpolar and polar regions, Geochim. Cosmochim. Ac., 131, 213-226, 2014.

Hochmuth, K., Gohl, K., Leitchenkov, G., Sauermilch, I., Whittaker, J. M., Uenzelmann-Neben, G., Davy, B., and De Santis, L.: The evolving paleobathymetry of the circum-Antarctic Southern Ocean since $34 \mathrm{Ma}$ - a key to understanding past cryosphere-ocean developments, Geochem. Geophy. Geosy., 11, e2020GC009122, https://doi.org/10.1029/2020GC009122, 2020.

Hoem, F. S., Valero, L., Evangelinos, D., Escutia, C., Duncan, B., McKay, R. M., Brinkhuis, H., Sangiorgi, F., and Bijl, P.: Temperate Oligocene surface ocean conditions offshore of Cape Adare, Ross Sea, Antarctica [Data set]. Climate of the past, Zenodo, https://doi.org/10.5281/zenodo.5036609, 2021.

Hopmans, E. C., Weijers, J. W., Schefuß, E., Herfort, L., Damsté, J. S. S., and Schouten, S.: A novel proxy for terrestrial organic matter in sediments based on branched and isoprenoid tetraether lipids, Earth Planet. Sci. Lett., 224, 107-116, https://doi.org/10.1016/j.epsl.2004.05.012, 2004.

Hopmans, E. C., Schouten, S., and Damsté, J. S. S.: The effect of improved chromatography on GDGTbased palaeoproxies, Org. Geochem., 93, 1-6, https://doi.org/10.1016/j.orggeochem.2015.12.006, 2016.

Houben, A. J., Bijl, P. K., Guerstein, G. R., Sluijs, A., and Brinkhuis, H.: Malvinia escutiana, a new biostratigraphically important Oligocene dinoflagellate cyst from the 
Southern Ocean, Rev. Palaeobot. Palyno., 165, 175-182, https://doi.org/10.1016/j.revpalbo.2011.03.002, 2011.

Houben, A. J., Bijl, P. K., Pross, J., Bohaty, S. M., Passchier, S., Stickley, C. E., Röhl, U., Sugisaki, S., Tauxe, L., and van de Flierdt, T.: Reorganization of Southern Ocean plankton ecosystem at the onset of Antarctic glaciation, Science, 340, 341-344, https://doi.org/10.1126/science.1223646, 2013.

Houben, A. J., Bijl, P. K., Sluijs, A., Schouten, S., and Brinkhuis, H.: Late Eocene Southern Ocean cooling and invigoration of circulation preconditioned Antarctica for fullscale glaciation, Geochem. Geophy. Geosy., 20, 2214-2234, https://doi.org/10.1029/2019GC008182, 2019.

Huber, M. and Caballero, R.: The early Eocene equable climate problem revisited, Clim. Past, 7, 603-633, https://doi.org/10.5194/cp-7-603-2011, 2011.

Huerta, A. D. and Harry, D. L.: The transition from diffuse to focused extension: Modeled evolution of the West Antarctic Rift system, Earth Planet. Sci. Lett., 255, 133-147, https://doi.org/10.1016/j.epsl.2006.12.011, 2007.

Jovane, L., Florindo, F., Wilson, G., de Almeida Pecchiai Saldanha Leone, S., Hassan, M. B., Rodelli, D., and Cortese, G.: Magnetostratigraphic Chronology of a Cenozoic Sequence From DSDP Site 274, Ross Sea, Antarctica, Front. Earth Sci., 8, 155-169, https://doi.org/10.3389/feart.2020.563453, 2020.

Juggins, S.: C2: Software for ecological and palaeoecological data analysis and visualisation (user guide version 1.5), Newcastle upon Tyne: Newcastle University, Newcastle upon Tyne, The United Kingdom, 77, 2007.

Kalanetra, K. M., Bano, N., and Hollibaugh, J. T.: Ammoniaoxidizing Archaea in the Arctic Ocean and Antarctic coastal waters, Environ. Microbiol., 11, 2434-2445, https://doi.org/10.1111/j.1462-2920.2009.01974.x, 2009.

Kim, J.-H., Van der Meer, J., Schouten, S., Helmke, P., Willmott, V., Sangiorgi, F., Koç, N., Hopmans, E. C., and Damsté, J. S. S.: New indices and calibrations derived from the distribution of crenarchaeal isoprenoid tetraether lipids: Implications for past sea surface temperature reconstructions, Geochim. Cosmochim. Ac., 74, 4639-4654, https://doi.org/10.1016/j.gca.2010.05.027, 2010.

Kulhanek, D. K., Levy, R. H., Clowes, C. D., Prebble, J. G., Rodelli, D., Jovane, L., Morgans, H. E., Kraus, C., Zwingmann, H., and Griffith, E. M.: Revised chronostratigraphy of DSDP Site 270 and late Oligocene to early Miocene paleoecology of the Ross Sea sector of Antarctica, Global Planet. Change, 178, 46-64, https://doi.org/10.1016/j.gloplacha.2019.04.002, 2019.

Lear, C. H., Elderfield, H., and Wilson, P. A.: Cenozoic deep-Sea temperatures and global ice volumes from $\mathrm{Mg} / \mathrm{Ca}$ in benthic foraminiferal calcite, Science, 287, 269-272, https://doi.org/10.1126/science.287.5451.269, 2000.

Levy, R. H. and Harwood, D. M.: Tertiary marine palynomorphs from the McMurdo Sound erratics, Antarctica, Paleobiology and Paleoenvironments of Eocene Rocks: McMurdo Sound, East Antarctica, 76, 183-242, 2000.

Levy, R., Harwood, D., Florindo, F., Sangiorgi, F., Tripati, R., von Eynatten, H., Gasson, E., Kuhn, G., Tripati, A., DeConto, R., Fielding, C., Field, B., Golledge, N., McKay, R., Naish, T., Olney, M., Pollard, D., Schouten, S., Talarico, F., Warny, S., Willmott, V., Acton, G., Panter, K., Paulsen, T., Taviani, M., and Team, S. M. S. S.: Antarctic ice sheet sensitivity to atmospheric $\mathrm{CO}_{2}$ variations in the early to mid-Miocene, P. Natl. Acad. Sci. USA, 113, 3453-3458, https://doi.org/10.1073/pnas.1516030113, 2016.

Levy, R. H., Meyers, S. R., Naish, T. R., Golledge, N. R., McKay, R. M., Crampton, J. S., DeConto, R. M., De Santis, L., Florindo, F., Gasson, E. G. W., Harwood, D. M., Luyendyk, B. P., Powell, R. D., Clowes, C., and Kulhanek, D. K.: Antarctic ice-sheet sensitivity to obliquity forcing enhanced through ocean connections, Nat. Geosci., 12, 132-137, https://doi.org/10.1038/s41561-0180284-4, 2019.

Liebrand, D., de Bakker, A. T., Beddow, H. M., Wilson, P. A., Bohaty, S. M., Ruessink, G., Pälike, H., Batenburg, S. J., Hilgen, F. J., and Hodell, D. A.: Evolution of the early Antarctic ice ages, P. Natl. Acad. Sci., 114, 3867-3872, 2017.

Locarnini, R. A., Mishonov, A. V., Baranova, O. K., Boyer, T. P., Zweng, M. M., Garcia, H. E., Reagan, J. R., Seidov, D., Weathers, K. W., Paver, C. R., and Smolyar, I. V.: World Ocean Atlas 2018, Volume 1: Temperature, edited by: Mishonov, A., Technical Editor, NOAA Atlas NESDIS 81, U.S. Government Printing Office, Washington, D. C., 52 pp., 2019.

Macphail, M.: The Sabrina Microfloras of East Antarctica: Late Cretaceous Paleogene or reworked?, Palynology, 2021, 1-12, https://doi.org/10.1080/01916122.2021.1921070, 2021.

Marret, F., Bradley, L., de Vernal, A., Hardy, W., Kim, S.-Y., Mudie, P., Penaud, A., Pospelova, V., Price, A. M., and Radi, T.: From bi-polar to regional distribution of modern dinoflagellate cysts, an overview of their biogeography, Mar. Micropaleontol., 159, 101753, https://doi.org/10.1016/j.marmicro.2019.101753, 2019.

Massana, R., Taylor, L. T., Murray, A. E., Wu, K. Y., Jeffrey, W. H., and DeLong, E. F.: Vertical distribution and temporal variation of marine planktonic archaea in the Gerlache Strait, Antarctica, during early spring, Limnol. Oceanogr., 43, 607-617, https://doi.org/10.4319/lo.1998.43.4.0607, 1998.

McKay, R., Barrett, P., Levy, R., Naish, T., Golledge, N., and Pyne, A.: Antarctic Cenozoic climate history from sedimentary records: ANDRILL and beyond, Philos. T. Roy. Soc. A, 374, 20140301, https://doi.org/10.1098/rsta.2014.0301, 2016.

Müller, R. D., Cannon, J., Qin, X., Watson, R. J., Gurnis, M., Williams, S., Pfaffelmoser, T., Seton, M., Russell, S. H., and Zahirovic, S.: GPlates: building a virtual Earth through deep time, Geochem. Geophy. Geosy., 19, 2243-2261, https://doi.org/10.1029/2018GC007584, 2018.

Naish, T. R., Woolfe, K. J., Barrett, P. J., Wilson, G. S., Atkins, C., Bohaty, S. M., Bücker, C. J., Claps, M., Davey, F. J., and Dunbar, G. B.: Orbitally induced oscillations in the East Antarctic ice sheet at the Oligocene/Miocene boundary, Nature, 413, 719-723, https://doi.org/10.1038/35099534, 2001.

O'Brien, C. L., Huber, M., Thomas, E., Pagani, M., Super, J. R., Elder, L. E., and Hull, P. M.: The enigma of Oligocene climate and global surface temperature evolution, P. Natl. Acad. Sci. USA, 117, 25302-25309, https://doi.org/10.1073/pnas.2003914117, 2020.

Orsi, A. H. and Wiederwohl, C. L.: A recount of Ross Sea waters, Deep-Sea Res. Pt. II, 56, 778-795, https://doi.org/10.1016/j.dsr2.2008.10.033, 2009.

Pälike, H., Norris, R. D., Herrle, J. O., Wilson, P. A., Coxall, H. K., Lear, C. H., Shackleton, N. J., Tripati, A. K., and Wade, B. S.: The heartbeat of the Oligocene climate system, Science, 314, 1894-1898, https://doi.org/10.1126/science.1133822, 2006. 
Passchier, S., Ciarletta, D. J., Henao, V., and Sekkas, V.: Sedimentary processes and facies on a high-latitude passive continental margin, Wilkes Land, East Antarctica, Geological Society, London, Special Publications, 475, 181-201, https://doi.org/10.1144/SP475.3, 2019.

Paxman, G. J., Jamieson, S. S., Hochmuth, K., Gohl, K., Bentley, M. J., Leitchenkov, G., and Ferraccioli, F.: Reconstructions of Antarctic topography since the EoceneOligocene boundary, Palaeogeogr. Palaeocl., 535, 109346, https://doi.org/10.1016/j.palaeo.2019.109346, 2019.

Pearson, A., Huang, Z., Ingalls, A., Romanek, C., Wiegel, J., Freeman, K. H., Smittenberg, R., and Zhang, C.: Nonmarine crenarchaeol in Nevada hot springs, Appl. Environ. Microbiol., 70, 5229-5237, https://doi.org/10.1128/AEM.70.9.5229-5237.2004, 2004.

Pérez, L. F., De Santis, L., McKay, R. M., Larter, R. D., Ash, J., Bart, P. J., Böhm, G., Brancatelli, G., Browne, I., and Colleoni, F.: Early and middle Miocene ice sheet dynamics in the Ross Sea: Results from integrated core-log-seismic interpretation, GSA Bulletin, https://doi.org/10.1130/B35814.1, 2021.

Peterse, F., Kim, J.-H., Schouten, S., Kristensen, D. K., Koç, N., and Damsté, J. S. S.: Constraints on the application of the MBT/CBT palaeothermometer at high latitude environments (Svalbard, Norway), Org. Geochem., 40, 692-699, https://doi.org/10.1016/j.orggeochem.2009.03.004, 2009.

Prebble, J., Hannah, M., and Barrett, P.: Changing Oligocene climate recorded by palynomorphs from two glacio-eustatic sedimentary cycles, Cape Roberts Project, Victoria Land Basin, Antarctica, Palaeogeogr. Palaeocl., 231, 58-70, https://doi.org/10.1016/j.palaeo.2005.07.026, 2006.

Prebble, J., Crouch, E., Carter, L., Cortese, G., Bostock, H., and Neil, H.: An expanded modern dinoflagellate cyst dataset for the Southwest Pacific and Southern Hemisphere with environmental associations, Mar. Micropaleontol., 101, 33-48, https://doi.org/10.1016/j.marmicro.2013.04.004, 2013.

Richey, J. N. and Tierney, J. E.: GDGT and alkenone flux in the northern Gulf of Mexico: Implications for the $\mathrm{TEX}_{86}$ and $U_{37}^{\mathrm{K}^{\prime}}$ paleothermometers, Paleoceanography, 31, 1547-1561, https://doi.org/10.1002/2016PA003032, 2016.

Salabarnada, A., Escutia, C., Röhl, U., Nelson, C. H., McKay, R., Jiménez-Espejo, F. J., Bijl, P. K., Hartman, J. D., Strother, S. L., Salzmann, U., Evangelinos, D., López-Quirós, A., Flores, J. A., Sangiorgi, F., Ikehara, M., and Brinkhuis, H.: Paleoceanography and ice sheet variability offshore Wilkes Land, Antarctica - Part 1: Insights from late Oligocene astronomically paced contourite sedimentation, Clim. Past, 14, 991-1014, https://doi.org/10.5194/cp-14-991-2018, 2018.

Sangiorgi, F., Bijl, P. K., Passchier, S., Salzmann, U., Schouten, S., McKay, R., Cody, R. D., Pross, J., Van De Flierdt, T., and Bohaty, S. M.: Southern Ocean warming and Wilkes Land ice sheet retreat during the mid-Miocene, Nat. Commun., 9, 317328, https://doi.org/10.1038/s41467-017-02609-7, 2018.

Scher, H. D., Bohaty, S. M., Zachos, J. C., and Delaney, M. L.: Twostepping into the icehouse: East Antarctic weathering during progressive ice-sheet expansion at the Eocene-Oligocene transition, Geology, 39, 383-386, https://doi.org/10.1130/G31726.1, 2011.

Scher, H. D., Whittaker, J. M., Williams, S. E., Latimer, J. C., Kordesch, W. E. C., and Delaney, M. L.: Onset of Antarctic Circumpolar Current 30 million years ago as Tasma- nian Gateway aligned with westerlies, Nature, 523, 580-583, https://doi.org/10.1038/nature14598, 2015.

Schouten, S., Hopmans, E. C., Schefuß, E., and Damste, J. S. S.: Distributional variations in marine crenarchaeotal membrane lipids: a new tool for reconstructing ancient sea water temperatures?, Earth Planet. Sci. Lett., 204, 265-274, https://doi.org/10.1016/S0012-821X(02)00979-2, 2002.

Schouten, S., Hopmans, E. C., Rosell-Melé, A., Pearson, A., Adam, P., Bauersachs, T., Bard, E., Bernasconi, S. M., Bianchi, T. S., and Brocks, J. J.: An interlaboratory study of $\mathrm{TEX}_{86}$ and BIT analysis of sediments, extracts, and standard mixtures, Geochem. Geophy. Geosy., 14, 5263-5285, https://doi.org/10.1002/2013GC004904, 2013.

Shen, Q., Wang, H., Shum, C., Jiang, L., Hsu, H. T., and Dong, J.: Recent high-resolution Antarctic ice velocity maps reveal increased mass loss in Wilkes Land, East Antarctica, Scientific Reports, 8, 4477, https://doi.org/10.1038/s41598-018-22765-0, 2018.

Sinninghe Damsté, J. S.: Spatial heterogeneity of sources of branched tetraethers in shelf systems: The geochemistry of tetraethers in the Berau River delta (Kalimantan, Indonesia), Geochim. Cosmochim. Ac., 186, 13-31, https://doi.org/10.1016/j.gca.2016.04.033, 2016.

Sinninghe Damsté, J. S., Ossebaar, J., Abbas, B., Schouten, S., and Verschuren, D.: Fluxes and distribution of tetraether lipids in an equatorial African lake: constraints on the application of the $\mathrm{TEX}_{86}$ palaeothermometer and BIT index in lacustrine settings, Geochim. Cosmochim. Ac., 73, 4232-4249, https://doi.org/10.1016/j.gca.2009.04.022, 2009.

Sluijs, A. and Brinkhuis, H.: A dynamic climate and ecosystem state during the Paleocene-Eocene Thermal Maximum: inferences from dinoflagellate cyst assemblages on the New Jersey Shelf, Biogeosciences, 6, 1755-1781, https://doi.org/10.5194/bg-61755-2009, 2009

Sluijs, A., Pross, J., and Brinkhuis, H.: From greenhouse to icehouse; organic-walled dinoflagellate cysts as paleoenvironmental indicators in the Paleogene, Earth-Sci. Rev., 68, 281-315, https://doi.org/10.1016/j.earscirev.2004.06.001, 2005.

Speelman, E. N., Sewall, J. O., Noone, D., Huber, M., von der Heydt, A., Damsté, J. S., and Reichart, G.-J.: Modeling the influence of a reduced equator-to-pole sea surface temperature gradient on the distribution of water isotopes in the Early/Middle Eocene, Earth Planet. Sci. Lett., 298, 57-65, https://doi.org/10.1016/j.eps1.2010.07.026, 2010.

Stickley, C. E., Brinkhuis, H., Schellenberg, S. A., Sluijs, A., Röhl, U., Fuller, M., Grauert, M., Huber, M., Warnaar, J., and Williams, G. L.: Timing and nature of the deepening of the Tasmanian Gateway, Paleoceanography, 19, PA4026, https://doi.org/10.1029/2004PA001014, 2004.

Stocchi, P., Escutia, C., Houben, A. J., Vermeersen, B. L., Bijl, P. K., Brinkhuis, H., DeConto, R. M., Galeotti, S., Passchier, S., and Pollard, D.: Relative sea-level rise around East Antarctica during Oligocene glaciation, Nat. Geosci., 6, 380-384, https://doi.org/10.1038/ngeo1783, 2013.

Taylor, K. W., Huber, M., Hollis, C. J., Hernandez-Sanchez, M. T., and Pancost, R. D.: Re-evaluating modern and Palaeogene GDGT distributions: Implications for SST reconstructions, Global Planet. Change, 108, 158-174, https://doi.org/10.1016/j.gloplacha.2013.06.011, 2013. 
Williams, G. L., Fensome, R. A., and MacRae, R. A.: The Lentin and Williams Index of Fossil Dinoflagellates 2017 Edition, American Association of Stratigraphic Palynologists Foundation (AASP), Contributions Series Number 48, Dallas, Texas, USA, 2017.

Wilson, D. S., Pollard, D., DeConto, R. M., Jamieson, S. S., and Luyendyk, B. P.: Initiation of the West Antarctic Ice Sheet and estimates of total Antarctic ice volume in the earliest Oligocene, Geophys. Res. Lett., 40, 4305-4309, 2013.

Wouters, B., Martin-Español, A., Helm, V., Flament, T., van Wessem, J. M., Ligtenberg, S. R., Van den Broeke, M. R., and Bamber, J. L.: Dynamic thinning of glaciers on the Southern Antarctic Peninsula, Science, 348, 899-903, https://doi.org/10.1126/science.aaa5727, 2015.

Zachos, J. C., Stott, L. D., and Lohmann, K. C.: Evolution of early Cenozoic marine temperatures, Paleoceanography, 9, 353-387, https://doi.org/10.1029/93PA03266, 1994.

Zachos, J. C., Dickens, G. R., and Zeebe, R. E.: An early Cenozoic perspective on greenhouse warming and carbon-cycle dynamics, Nature, 451, 279-283, https://doi.org/10.1038/nature06588, 2008.

Zhang, Y. G., Zhang, C. L., Liu, X.-L., Li, L., Hinrichs, K.U., and Noakes, J. E.: Methane Index: A tetraether archaeal lipid biomarker indicator for detecting the instability of marine gas hydrates, Earth Planet. Sci. Lett., 307, 525-534, https://doi.org/10.1016/j.eps1.2011.05.031, 2011.
Zhang, Y. G., Pagani, M., and Wang, Z.: Ring Index: A new strategy to evaluate the integrity of TEX86 paleothermometry, Paleoceanography, 31, 220-232, https://doi.org/10.1002/2015PA002848, 2016.

Zonneveld, K. A. F., Versteegh, G. J. M., Kasten, S., Eglinton, T. I., Emeis, K.-C., Huguet, C., Koch, B. P., de Lange, G. J., de Leeuw, J. W., Middelburg, J. J., Mollenhauer, G., Prahl, F. G., Rethemeyer, J., and Wakeham, S. G.: Selective preservation of organic matter in marine environments; processes and impact on the sedimentary record, Biogeosciences, 7, 483-511, https://doi.org/10.5194/bg-7-483-2010, 2010.

Zonneveld, K. A. F., Marret, F., Versteegh, G. J. M., Bogus, K., Bonnet, S., Bouimetarhan, I., Crouch, E., de Vernal, A., Elshanawany, R., Edwards, L., Esper, O., Forke, S., Grosfjeld, K., Henry, M., Holzwarth, U., Kielt, J. F., Kim, S. Y., Ladouceur, S., Ledu, D., Chen, L., Limoges, A., Londeix, L., Lu, S. H., Mahmoud, M. S., Marino, G., Matsouka, K., Matthiessen, J., Mildenhal, D. C., Mudie, P., Neil, H. L., Pospelova, V., Qi, Y. Z., Radi, T., Richerol, T., Rochon, A., Sangiorgi, F., Solignac, S., Turon, J. L., Verleye, T., Wang, Y., Wang, Z. H., and Young, M.: Atlas of modern dinoflagellate cyst distribution based on 2405 data points, Rev. Palaeobot. Palyno., 191, 1-197, https://doi.org/10.1016/j.revpalbo.2012.08.003, 2013. 